\title{
«RECIBIDA Y ADMITIDA DE TODOS...» \\ LA LECTURA DE LA HISTORIA EN LA SOCIEDAD MADRILEÑA DEL SIGLO DE ORO
}

por

\author{
José Manuel Prieto Bernabé \\ Instituto de Historia. CSIC
}

RESUMEN: En este trabajo se pretende relacionar el mundo de la literatura bistórica con la realidad lectora de la sociedad madrileña de los siglos XVI y XVII. Una época en la que durante el periodo 1550 a 1650 se fueron modelando las condiciones necesarias para que una ciudad como Madrid, sin apenas pasado tipográfico, pero con una gran proyección política, económica y demográfica se convirtiera en un punto de referencia de la llamada cultura escrita. Un amplio periodo en el que los recursos de la producción y distribución impresa, a pesar de sus dificultades estructurales, favorecieron, entre otros intereses editoriales, disciplinas como la historia, convirtiéndola en una literatura probativa y de estrategia política que, al mismo tiempo supo preparar un proyecto comunitario de recuperación de la conciencia nacional. Era necesario desde la enseñanza del pasado construir el presente y ordenar el futuro. El plural y entusiasta tejido social madrileño, aun a caballo entre la práctica oral y el testimonio escrito, llegaron a conformar amplias y emancipadas estrategias de consumo bistoriográfico que, desde los recuerdos de la tradición literaria antigua y medieval se afianzaron en las modernas formas de entender la disciplina.

Palabras Clave: Madrid. Cultura escrita. Libros de historia. Historiografía. Siglo de Oro. Lectura. Lectores.

ABSTRACT: This work attempts to relate the world of bistorical literature to the reading reality of Madrid society in the sixteenth and seventeenth centuries. From 1550 to 1560 , the necessary conditions were forged whereby a city like Madrid, without a significant history of printing but with a great political, economic and demographic projection, became a reference point of written culture. The production and distribution of printed material favoured disciplines like bistory, which became an instrument of political strategy and a means of acbieving a collective recovery of national consciousness. Through education about the past, it was necessary to construct the present and order the future. The complex fabric of Madrid society, halfway between 
oral practice and the written testimony, transformed strategies of historiograpbical consumption that adhered to modern forms of understanding the discipline.

KEY WORDS: Madrid. Written culture. Historical books. Historiography. Reading. Readers.

\author{
...ninguna cosa de letras se puede escribir que \\ comúnmente pueda aprovechar a tantos, $y$ asi sea \\ recibida y admitida de todos, como es la Historia...
}

Pedro de Mejía

\title{
INTRODUCCIÓN
}

A modo de preámbulo querría expresar algunos elementos sobre la gran novedad que supuso el libro impreso en la sociedad altomoderna, y, con ellos, algunos otros que ayuden a justificar la posición y significado social que tomó la amplia producción historiográfica y su lectura respecto de esa nueva realidad.

Para empezar, conviene no olvidar que la entrada del material impreso en la sociedad de los siglos XVI y XVII se hizo de una manera gradual y pausada proliferando allí donde los puntos esenciales en los que se apoyaba la circulación y difusión de los modelos culturales aún se veían ampliamente supeditados a los dictados de la palabra y la imagen ${ }^{1}$.

Una primera idea, por tanto, es la de comprender el hecho de que en ningún caso la adaptación a la nueva realidad comprometida por el arte tipográfico fue automática. El nuevo libro no alteró de forma terminante las arraigadas estructuras del manuscrito, cuya circulación en los tiempos modernos no debe entenderse como un signo arcaico o «medievalizante», sino como la natural respuesta a unas necesidades concretas que aun se mantuvieron vigentes gracias a la relativa personalización e inmediación demostrada por la escritura manual ${ }^{2}$. A pesar de ello, la aculturación tipografía hizo que el llamado escrito ad

$\therefore \quad$ i Estas ideas pueden ampliarse en con los trabajos ya clásicos de CHARTIER, Roger: Libros, lecturas y lectores en la Edad Moderna, Madrid, 1993. En especial el cap. I.: «De la historia del libro a la historia de la lectura». Igualmente, resulta imprescindible por su planteamiento renovador el de BOUZA ÁLvarez, Fernando J.: Del escribano a la biblioteca. La civilización escrita europea en la alta edad Moderna (siglos XV-XVII), Madrid, 1992. Otra aproximación más sencilla al tema: PRIETO BERNABÉ, José Manuel: La seducción de papel. El libro y la lectura en la España del Siglo de Oro, Madrid, Arco/Libros, 2000:

2 Vid. Bouza Álvarez, Fernando J.: Comunicación, conocimiento y memoria en la España de los siglos XVI y XVII, Salamanca; Publicaciones del Semyr, 1999, pp. 101-103. Más detalles acerca de la circulación de manuscritos en España y Portugal durante los siglos XVI y XVII, véase, del mismo autor: Corre manuscrito. Una bistoria cultural del Siglo de Oro, Madrid, Marcial Pons, 2001. También CHARTIER, Roger: «El manuscrito en la época del impreso. Lecturas y reflexiones», en Manuel Peña 
vivum - sin llegar hacerle desaparecer- dejara de ser único. El nuevo material impreso fue constituyendo un factor de cambio en las prácticas de la cultura escrita, tanto desde el punto de vista técnico como intelectual.

Pero el moderno artefacto resultó ser un competidor formidable: su potencialidad difusora, su capacidad de llegar a todas partes, a todos los ambientes y a cualquier género de personas sobre la base de un considerable número de copias a precio relativamente asequible, favoreció la rápida e intensiva divulgación de nuevas ideas, y de un inédito estilo de vivir y ver las cosas, una conquista que hasta el momento había sido una empresa casi impensable.

La misma sociedad altomoderna fue testigo de la transformación de unos concretos procedimientos y actitudes cuyo porvenir ya no podían entenderse sin la escritura, en cualquiera de sus formas. Un portalón instrumental por el que se entraba en un nuevo tiempo: «el hombre que no sabe leer, escribir y contar, perfecto hombre no se puede llamar...» afirmaba Alonso González Bastones a mediados del siglo XVII ${ }^{3}$.

El libro de molde fue gradualmente alterando aquellas tradicionales prácticas de comunicación y empezó a convertirse en la norma, incluso en el símbolo y vector eficaz de la difusión cultural de la Europa moderna ${ }^{4}$. Su fuerza no dejó de expandirse en la mentalidad de los hombres de los siglos XVI y XVII. Fue capaz de abrir un mundo más dilatado de situaciones y actividades que las ofrecidas hasta entonces. Así, por ejemplo, los modos de lectura propios de la imprenta contribuyeron a que el lector moderno adquiriera una nueva predisposición mental recibiendo los mensajes de forma más resuelta, normalizada y contrastada.

Se fue acrecentando y consolidando una cultura basada en la lengua, pero sobre todo, insisto, en su forma escrita. Una cultura de alguna manera estrenada y asumida principalmente como lectura de libros: "que no hay otro saber - escribía Baltasar Gracián- sino el que se halla en los inmortales caracteres de los libros» ${ }^{5}$. Y en ese espacio de transformación, la modernidad se estableció de una manera incontestable. Ahora lo precursor —al menos para las mentes más inquietas - era alentar la labor de autores y editores al objeto de que se escribieran cada vez más libros, se multiplicaran en los talleres de imprenta y por medio de libreros se ofrecieran al mayor número posible de lectores que, en definitiva, eran los que darían la última dimensión de autoridad.

Díaz, Pedro Ruiz Pérez y Julián Solana Pujalte (coords.): La cultura del libro en la Edad Moderna. Andalucía y América, Córdoba, Servicio de Publicaciones de la Universidad de Córdoba, 2001, pp. 21-35.

3 Cit. por Bouza Álvarez, Fernando J.: Comunicación, conocimiento y memoria..., op. cit., p. 108.

4 REVel, Jean: «La cultura difundida» en La cultura del Renaixement, Homenatge al P. Miguel Batllori, Manuscrits, Revista de Historia Moderna, I, (1993) pp. 159-167.

5 Cit. por MARAVALl, José Antonio: "La concepción del saber en una sociedad tradicional», en Estudios de bistoria del pensamiento español, Madrid, Ediciones de Cultura Hispánica, 1973, p. 252. 
Además, incluso, por la posibilidad de producción y difusión a gran escala, la imprenta representó, desde la fijación del texto, la mejor herramienta que tuvo el poder establecido para consolidar de forma uniforme y duradera el saber que interesaba divulgar, sin olvidarse de ir empleando con especial pericia las posibilidades que el formidable ingenio supuso para los grandes movimientos propagandísticos de la alta Edad Moderna. Así, por ejemplo, en 1573, Francisco Hurtado de Mendoza, por aquel entonces embajador de Felipe II en la corte cesárea, y atento conocedor de las prácticas editoriales empleadas por los protestantes, propuso una ofensiva tipográfica desde el lado católico: «ya no nos quedaba otro remedio contra las blasfemias que aquí pasan, sino el imprimir libros para reprimirlas» ${ }^{6}$.

Acaso por haber demostrado un mayor grado de asignación de ideas que con el tradicional manuscrito, el modo de escritura impreso se convierte, conscientemente, en una herramienta política de primer orden. Y, de forma análoga, en el otro supremo recurso: el de la "salvación" 7 , inclusive en el principal aparejo de la autoafirmación del conocimiento, deseoso de superar los angostos márgenes de la cultura medieval. Y para ello, no dejó de contar con las nuevas relaciones entre autores y receptores, con la necesidad de ampliar para su consumo los modelos literarios, y con un mejor preparado público lector, tanto en lengua latina como en romance . $^{2}$

Las colecciones particulares de libros guardaron una composición muy diversa, dependiendo, obviamente, de los intereses intelectuales de cada propietario. Sin embargo, las grandes líneas europeas de distribución del impreso y los mismos libreros también supieron condicionar los gustos y en consecuencia

6 Cit. por Bouza Álvarez. Fernando J.: Comunicación, conocimiento y memoria..., op. cit., p. 67. Del mismo autor y sobre don Francisco Hurtado de Mendoza: «Docto y devoto. La biblioteca del marqués de Almazán y conde de Monteagudo. (Madrid, 1591)", en F. Edelmayer (ed.): Hispania Austria die epoche Philipps II. (1556-1598), Viena, 1999, pp. 247-310. Igualmente, acerca de la propaganda y la utilización de la imprenta en tiempos de Felipe II, véase del mismo autor: «Monarchie en lettres d'imprimerie. Typographie et propagande au temps de Philippe II", en Revue d'Histoire Moderne et Contemporaine, 41, (1994), pp. 206-220.

7 Vid. BOUZA ÁlVAREZ, Fernando J:: «Contrarreforma y tipografía. ¿Nada más que rosarios en sus manos?» en Cuadernos de Historia Moderna, 16, (1995), pp. 73-87.

8 Cfr. LÓPEZ-CoRdón CORTEZo, María Victoria: «Libros y pedagogía», en López-Vidriero, María Luisa y Cátedra, Pedro M.: El libro Antiguo Español, III, El libro en Palacio y otros estudios bibliográficos, Salamanca, 1996, p. 150. Estudios sobre alfabetización en la España de los siglos XVI y XVII, entre ellos los de los profesores Viñao; Larquie; Rodríguez-Bennassar; Tapia y S. T. Nalle, nos muestran cómo al menos la evolución temporal de la alfabetización de la población urbana, en líneas generales, disfrutó de unos niveles que, dependiendo de la edad, sexo y categoría socio profesional, podrían estimarse de aceptables o, al menos, equiparables a los de otros núcleos urbanos europeos. Vid. VIÑAO FRAGO, Antonio: "Alfabetización y primeras letras (siglos XVI-XVII)», en Antonio Castillo (comp.), Escribir y leer en el siglo de Cervantes, Barcelona, Gedisa, 1999, en especial, pp. 46-52.

Hispania, LXV/3, núm. 221 (2005) 877-938 
la formación y el espíritu de muchas bibliotecas9. Se fue, entretanto, incrementando la confrontación, la selección y la crítica de las obras que habían de leerse. Textos no sólo técnicos y profesionales (lingüísticos, médicos, jurídicos), sino también de carácter literario, sacro e histórico. Toda una abierta e inagotable gama de conocimientos y una capaz producción literaria, que en el caso concreto de la historia (materia a la que dedicamos estas páginas) llegó a manifestar un carácter innovador, si cabe menos heredado y conservador que el propuesto hasta entonces por otras realidades literarias.

Hay una principal consideración, y es la del continuo y general incremento de la producción historiográfica nacional e internacional puesta a disposición de las necesidades de la comunidad lectora, en este caso española. Una producción que vio multiplicar ampliamente sus versiones originales y traducciones. Un fenómeno que para Maravall estuvo en el interés demostrado por buena parte de nuestros autores de tomar el modelo historiográfico como cimiento para desarrollar las propias inquietudes intelectuales. Dos ejemplos, relativamente contrarios, son los propuestos: el de Antonio de Guevara, un escritor poco proclive a apropiarse de la labor de historiador, pero que, sin embargo, toma las formas de la historia para encubrir sus propias invenciones; y el otro el de Pedro de Mejía, el autor prototipo de la nueva actitud de escribir historia como ocupación de primer nivel. Una posición intelectual que Mejía dejó explícitamente comentada en el prólogo a su Historia imperial y cesárea al advertir que su principal ocupación era la del cultivo de la historia, y su deber el de servir al rey y al estado ${ }^{10}$.

\section{Planteamiento y OBjetivos}

En estas páginas pretendemos exponer algunos elementos referidos a la realidad cultural de la sociedad madrileña de los siglos XVI y XVII, y, en concreto, reconstruir - a través de los testimonios de posesión de lectura - la dinámica de difusión social que representó la literatura histórica. Precisamente, la presencia de libros en una sociedad urbana suficientemente alfabetizada como lo fue la madrileña de los siglos altomodernos conformó una compleja representación cultural de ámbito colectivo que, a su vez, permitió dar origen a identidades sociales con-

\footnotetext{
9 Cátedra, Pedro M.: Nobleza y lectura en tiempos de Felipe II: la biblioteca de don Alonso Osorio, marqués de Astorga, Valladolid, Junta de Castilla y León, 2002, p. 196.

10 MARAVALl, José Antonio: «Sobre naturaleza e historia en el humanismo español», en Arbor, 64, 1951, pp. 481 y 482. Acerca de la historiografía en la primera mitad del siglo XVI, y en concreto sobre el estilo de historiar de Pedro Mejía y otros cronistas de Carlos V, vid. CUART MONER, Baltasar: «La historiografía áulica en la primera mitad del siglo XVI: los cronistas del emperador», en Carmen Codoñer y Juan Antonio González Iglesias (ed.), Antonio de Nebrija: Edad Media y Renacimiento, Salamanca, 1994, pp. 39-58.
}

Hispania, LXV/3, núm. 221 (2005) 877-938 
cretas y a prácticas propias mediante las cuales los individuos ponían de manifiesto su identificación con los distintos géneros literarios ${ }^{11}$.

En el caso que ahora nos ocupa, el de la literatura histórica, trataremos de ajustarnos a los postulados propuestos por el historiador de las prácticas culturales: Roger Chartier, cuando sugiere la necesidad de sobreponer la estructura del análisis cultural de lo social a la insuficiente historia social de la cultura. En otras palabras: llegar a incidir en las manifestaciones ideológico-culturales de una sociedad que, en definitiva, será la que determine el sentido real y crítico del concreto modelo histórico.

Los textos, los discursos de las obras mantienen una capacidad durable y universal, mientras que las maneras que tienen los receptores de aprehenderlos, de vivirlos, son cuanto menos diversas y cambiantes construidas entre la propuesta de un autor y la aprobación de los destinatarios. Nuestro objetivo, por tanto, estará en conocer desde el análisis de la difusión de la literatura histórica los vínculos y manifestaciones culturales que se establecieron con el público lector madrileño. En palabras de Roger Chartier «dibujar las áreas sociales donde circula cada «corpus» de textos y cada género de impresos. Partir de los objetos y no de las clases o los grupos» ${ }^{12}$.

A tenor de esta premisa inicial, y adecuando nuestro análisis al contenido de un elemento diferenciador social: las relaciones inventariadas de bibliotecas particulares, una primera razón estaría en hacer una evaluación sociológica de la posesión de esta parcela temática y conocer algunas de sus conductas lectoras. Es decir, desde las ya clásicas preguntas sobre: ¿qué interés despertó la literatura histórica entre los lectores-poseedores madrileños en los siglos XVI y XVII? ¿Cuáles fueron las obras más poseídas y su cuantía? Y ¿qué grado de difusión y proporción alcanzaron en relación con la diversidad de segmentos socio-profesionales de sus poseedores? Intentar mejorar estas interrogantes con otras relacionadas con las prácticas del consumo literario y establecer una equiparación cronológica respecto a la diferenciación de apropiaciones de algunas de las obras más poseídas.

Para tratar de dar respuesta a estas cuestiones hemos realizado un sondeo basándonos en el análisis de 1.307 bibliotecas particulares de muy distinta consideración y tamaño, base documental de un trabajo más amplio dedicado a la lectura en Madrid en el Siglo de Oro ${ }^{13}$. De los 4.126 inventarios particulares

\footnotetext{
11 A tenor de los valores globales obtenidos para Madrid en el periodo 1550 y 1650, los libros de Derecho se convierten en el primer elemento definidor de lectura con un 28,3 por ciento, seguido de cerca por los de Religión con un 27,4 por ciento. Entre ambos superan más de la mitad del conjunto de materias. Por su lado, los libros identificados dentro de las Bellas Letras quedan con un 18,7 por ciento, seguido por los de Historia con un 13,1 por ciento y, por último, los de Ciencias que alcanzan el 12,5 por ciento.

12 CHARTIER, Roger: El mundo como representación. Estudios sobre bistoria cultural, Barcelona, Gedisa, 1992, p. 109.

13 Vid. Prieto Bernabé, José Manuel.: Lectura y lectores. La cultura del impreso en el Madrid del Siglo de Oro (1550-1650), prólogo de Fernando Bouza, 2 vols., Mérida, E.R.E., 2004.
} 
examinados podemos adelantar que al menos el 31,7 por ciento tenía libros entre sus bienes y, por ende, sus propietarios podemos considerarlos como potenciales lectores.

Si reparamos en la naturaleza de las cifras anteriormente expuestas, no tenemos otra alternativa que estimar en su justa medida el uso de la exploración notarial de archivo y, por consiguiente de su documentación. En cualquier caso, a la hora de estudiar el libro y la lectura, el inventario tiene la gran virtud de permitir acceder con bastante equilibrio y puntualidad a las derivaciones de los periodos históricos y demás efectos del desarrollo cultural. Es de sobra conocido su facilidad para reconocer con un cierto detalle una importante nómina de lectores anónimos que con otra fuente hubieran pasado, posiblemente, inadvertidos.

Pero no queremos ocultar con ello los muchos inconvenientes que conlleva la aproximación a las fuentes notariales y, por ende al análisis de los datos obtenidos por medio de métodos estadísticos. A nadie se le escapa que estos problemas pueden originar inflexibilidades metodológicas que, a la postre casi siempre favorecen las dificultades interpretativas ${ }^{14}$. De ahí se desprende, por ejemplo, un principio de método según el cual el hallazgo de testimonios documentales con presencia de libros producidos por determinados individuos no autoriza a pensar automáticamente que practicaran una actividad lectora ${ }^{15}$. Tampoco ayudan a considerar que todo el consumo lector de un individuo fueran objetos adquiridos expresamente, $y$, menos aún que llegaran a conservarse. Es del todo sabido que la posibilidad de participar como espectador en una lectura oral y comunitaria, era asimismo una realidad que igualmente podía desfigurar el crédito ofrecido por los registros inventariados. Incluso, ya puestos a deshilachar, tampoco el uso y frecuentación del material impreso no siempre ni necesariamente tuvo que tomar la forma de libro ${ }^{16}$. Por tanto, la presencia de cualquier material escrito en los inventarios notariales —al menos

14 Sobre los problemas metodológicos y las dificultades presentadas por este tipo de estudios puede consultarse varios trabajos, entre otros: LAMARCA LANGA, Genaro: La cultura del libro en la época de la Ilustración: Valencia, 1740-1808, Valencia, 1994, pp. 17-42; CHEVALIER, Maxime: Lecturas y lectores en la España de los siglos XVI y XVII, Madrid, 1976, pp. 41-48; QuENIART, Jean: "L'utilisation des inventaires en histoire socioculturelle», en Las actes notariés, source de l'bistoire social, XVI-XIX siècle, Estrasburg, 1979, pp. 241-256. Otros estudios loables para reivindicar el alcance de los inventarios a la hora de conocer mejor los límites y las muchas cuestiones todavía pendientes, son los trabajos de INFANTES, Víctor: «La memoria de la biblioteca: el inventario» en El Libro Antiguo Español, V «El escrito en el Siglo de Oro. Prácticas y representaciones», dirigido por Pedro M. Cátedra, Augustin Redondo y María Luisa López-Vidriero, Salamanca, 1998, pp. 163-170; y «La ausencia en los inventarios de libros y bibliotecas», Bulletín Hispanique, 99 (1997), pp. 281-292.

15 Vid. Petrucci, Armando: Alfabetismo, escritura, sociedad, (prólogo de Roger Chartier y Jean Hébrard), Barcelona, 1999, p. 34.

16 Vid. CASTillo GómeZ, Antonio: «Del oído a la vista: espacios y formas de la publicidad del escrito (siglos XV-XVI), en José María Soto Rábanos (coord.): Pensamiento medieval bispano, (Homenaje a Horacio de Santiago-Otero), Madrid, 1998; pp. 473-496. 
para la época altomoderna - no significaba fehacientemente que fueran acompañados por una práctica efectiva y probada de lectura. Sin embargo, siguiendo la línea expuesta por Philippe Berger, también es cierto que la decisión de tener libros o sencillamente de conservarlos garantizaba por sí mismo un acto de lectura, sobre todo en aquel tiempo en donde la determinación personal de tener una obra manuscrita o impresa era si cabe un gesto más premeditado y consciente que hoy en día ${ }^{17}$.

Respecto de la fractura que concierne a la dificultad de la identificación de las obras, podemos decir que el problema empieza con la imprecisión de los criterios bibliográficos empleados en la época, si cabe más agudos cuando más se referían a obras de naturaleza histórica. En efecto, un rápido vistazo por cualquiera de los repertorios notariales con libros, permite comprobar el alto porcentaje de títulos en los que el propio campo de la representación disciplinar no se manifestaba con nitidez. Así, es fácil hallar obras con títulos a primera vista alejados de la disciplina histórica que, al objeto de reforzar su discurso, podían incluir (a modo de exempla) extensos testimonios históricos, mientras que, de igual modo, se puede tropezar con otras entradas de desarrollados enunciados y subtítulos, aparentemente de contenido histórico, que, sin embargo, se ocupaban poco o nada de la supuesta materia ofrecida. Ante este panorama que bien podríamos calificar de desconcertante conviene ser cuidadoso y considerar imprescindibles las continuas verificaciones como método a la hora de valorar el copioso campo ocupado por la historiografía en la Edad Moderna, una materia, desde mi punto de vista, en plena transformación y que, por tanto, aun exteriorizaba serias dificultades para considerarla en su integridad un saber homogéneo y estanco.

Es innegable que esta manifestación temática, por un lado tan rebosante y genérica, y, a veces, por otro tan enladrillada y miscelánea, ha determinado grandes problemas a la hora de su clasificación. De ahí, que tengamos no sólo un número considerable de obras sin reconocer, sino sin clasificar ${ }^{18}$.

Con relación a ésta espinosa cuestión sobre la ordenación bibliográfica se ha venido proponiendo por parte de algunos investigadores la conveniencia de

\footnotetext{
17 BERGER, Philippe: Libro y lectura en la Valencia del Renacimiento, vol. I, Madrid, 1987, p. 373.

18 La tradicional insuficiencia de la descripción en los títulos y autores con los consiguientes problemas de identificación han sido tónica general en otros trabajos. Así, por ejemplo, André Labarre al estudiar la lectura en Amiens en el siglo XVI (Le livre dans la vie aminoise du seizieme siècle, Paris, 1971), no identifica el 78 por ciento de los libros inventariados. Henri-Jean Martin en el caso de la lectura en París durante el siglo XVII (Livre, pouvoirs et societe de Paris au XVIIe siècle 15981701, Genève, 1969), llega al 66 por ciento. Mientras que Manuel Peña para el caso español, (Cataluña en el Renacimiento: libros y lengua. Barcelona, 1473-1600, Barcelona, 1996), lo reduce aproximadamente hasta el 30 por ciento. En mi trabajo sobre Madrid entre 1550-1650 (Lectura y lectores..., op. cit.) el número de libros no identificados asciende a uno de cada cuatro.
}

Hispania, LXV/3, núm. 221 (2005) 877-938 
ceñirse a los criterios clasificatorios propios de cada momento histórico ${ }^{19}$, evitando de esta manera nociones metodológicas actuales que pudieran entorpecer la correcta comprensión estructural de las antiguas colecciones bibliográficas: una iniciativa apropiada y perfectamente adaptable a grandes fondos de singular relevancia histórica o bibliográfica. Sin embargo, los peculiares problemas que presenta el procedimiento notarial, en su conjunto, inciden negativamente en la uniformidad explícita de la mayoría de los repertorios inventariados. Al menos, en un alto porcentaje de bibliotecas particulares -incluso entre las más relevantes y mejor inventariadas- puede apreciarse cómo las anotaciones referidas a los títulos de historia apenas aparecen reunidas en epígrafes distintivos. De igual modo, la escasa presencia de bibliotecas ordenadas bibliográficamente, o de las que a lo sumo presentan una estética de clasificación aleatoria y escasamente sistemática, han obligado, en nuestro caso, a buscar unos criterios mixtos en los que a partir de los grandes catálogos de bibliografía (Nicolás Antonio, Anselmo, Salvat, Palau, Catálogo Colectivo del Patrimonio Bibliográfico, etc.), combinados con la propia configuración interna de las bibliotecas estudiadas, y favorecidos por los títulos identificados, plantear un sistema de ordenación a través de la aplicación y cruce de los criterios de la época con las categorías actuales.

En nuestro caso, la tabla que proponemos hay que tomarla a la manera de una elemental guía sólo necesaria para la exposición del trabajo. tados:

La enumeración temática propuesta queda dividida en los siguientes apar-

1.- Historia eclesiástica.

2.- Historia civil.

2.1. Antigua (grecolatina).

2.2. Moderna.

2.2.1. General de España. Crónicas medievales y modernas. Historias de los distintos reinos de la monarquía. Corografías.

2.2.2. Historiografía indiana.

19 Vid. Bouza ÁlvareZ, Fernando J.: Del escribano a la biblioteca... op. cit., pp. 124-132; SÁNCHEZ MARIANA, Mariano: «Las clasificaciones bibliográficas: su estado a principios del siglo XVIII» en El Libro Antiguo Español, III «El libro en Palacio y otros estudios bibliográficos», dirigido por Pedro M. Cátedra y María Luisa López-Vidriero, Salamanca, 1996, pp. 279-284. Por su parte el profesor Cátedra al abordar el reparto de materias de la biblioteca del marqués de Astorga, se decide por seguir más o menos al pie de la letra los criterios artísticos o científicos de la división de las ciencias o de las disciplinas en tiempos de don Alonso de Osorio, bien es verdad que con algún que otro ajuste. Sin embargo, considera que aunque sea fácil explicar las pautas de clasificación impuestas por cada uno, lo importante y difícil es vislumbrar los criterios de lectura y de adquisición con los que los libros entraban a formar parte de una determinada biblioteca. CátedRA, Pedro M.: Nobleza y lectura..., op. cit., pp. 193 y 194. 
2.2.3. Universal (por naciones y pueblos).

2.3.1 Biografías. Necrologías. Exequias. Apologías. Epitafios. Cronologías. Tratados históricos. Avisos. Relaciones de sucesos. Correspondencias. Efemérides. Misceláneas. Epistolarios. Historias de nobles y casas nobiliarias. Heráldica. Genealogía.

3.- Viajes. Descripciones de países y regiones. Escritos geográficos.

\section{UNA APROXIMACIÓN ESTADÍSTICA}

En el caso de la ciudad de Madrid a lo largo de la segunda mitad del siglo XVI y primera del XVII se ha podido advertir un importante ascenso cuantitativo en la posesión de los niveles de literatura histórica. Una consecuencia que bien pudo deberse - además de por los incuestionables intereses lectores, políticos y editoriales - al despertar general de la personalidad histórica de la comunidad, en todo momento enardecida por un sentimiento originario marcado por la búsqueda de la autoafirmación de los valores de patriotismo e identidad nacional, pero no necesariamente entendidos como procedencia geográfica, sino a modo de colectividad humana asentada en un determinado territorio participe de unos mismos valores culturales y, a su vez, diferenciada de otras comunidades coetáneas.

En cualquier caso, el dato objetivo refleja que el número de libros de historia en las bibliotecas madrileñas analizadas - pese a los normales altibajosmantiene una línea ascendente señalada por una clara progresión hasta bien entrado el siglo XVII, en concreto hasta 1625. Como prueba, se pasa de un cinco por ciento entre 1550 y 1575 , a un 17 por ciento entre 1576 y 1600 , disparándose las cifras durante el primer cuarto del siglo XVII llegando a alcanzar el 51 por ciento. Desde ese techo máximo la proporción tomará una tendencia decreciente hasta situarse en el 27 por ciento para el periodo 16261650 que, pese a su bajada, si se compara con el tramo anterior, se llega a superar en torno a los diez puntos el valor máximo suscrito en el siglo XVI ${ }^{20}$.

Obviamente, no todos los géneros históricos gozaron de la misma atención del público lector madrileño. Aunque, bien es cierto que gracias -entre otros factores- a la influencia de la considerable producción editorial, el libro de historia se ganó la confianza de la sociedad en su más amplio espectro.

De los tres grandes bloques en que hemos dividido la materia, un primer apunte muestra la hegemonía de la historia civil sobre la eclesiástica ( 58 frente a 23 por ciento, respectivamente), quedando el otro apartado: viajes, descripciones de países y tratados geográficos con un 19 por ciento.

De la lectura histórica que se hizo en Madrid sobresale la mayoritaria presencia de escritores españoles: siete de cada diez libros inventariados están es-

20 Cfr. Prieto Bernabé, José Manuel: Lectura y lectores... op. cit., vol. I. p. 337. 
critos o traducidos por autores nacionales. Muy por debajo, pero con cifras reseñables, aparecen los autores italianos, es decir uno de cada cinco. El ocho por ciento restante se completa, aunque no de forma exclusiva, principalmente por escritores de nacionalidad portuguesa y francesa. Ni que decir tiene que los idiomas empleados en las ediciones mantienen más o menos su correspondencia con la procedencia de los autores.

En el plano social y profesional el aumento de la demanda del género historiográfico fue un fenómeno, como dijimos, suficientemente bien acogido por todos los grupos. Obviamente, se hizo mucho más ostensible en los estratos superiores de la pirámide social, alcanzando, incluso, en algunos de ellos unas cotas más que notables y diversificadas. Ahora bien, los desniveles también se hicieron notar: mientras que entre la nobleza, el alto funcionariado y alto clero se alcanzaron medias aproximadas de 28, 19 y 12 libros de historia por biblioteca, respectivamente, por el contrario, hay ciertos sectores sociales (artesanos, comerciantes, servidores domésticos) que no llegan a los dos libros. Incluso, dato a considerar, los profesionales liberales: abogados, licenciados, médicos, boticarios, etc., es decir, teóricamente preparados lectores, se caracterizan por un aparente «desinterés» por este tipo de literatura. Sus habitualmente copiosas y profesionalizadas librerías — que de forma absoluta superan el siete por ciento del total - ni siquiera alcanzan la menguada media de seis libros de historia por biblioteca.

En los restantes grupos estudiados: el funcionariado en general, es decir, cargos medios de la administración del Estado, oficiales de los distintos consejos, oficios palatinos o de Corte, cargos municipales o militares, etc.; el clero en su conjunto y con ellos los oficios artísticos (escultores, pintores, entalladores, doradores, etc.) mantienen unos valores medios bastante razonables (once, ocho y cinco libros de historia por biblioteca, respectivamente) muy de acuerdo con las características particulares de sus repertorios - sobre todo en los primeros- en donde su composición temática no sólo testimonia una apreciable vocación lectora, sino que en general solían responder a un patrón relativamente inalterable caracterizado por la diversidad de los títulos poseídos.

En el siguiente cuadro puede verse el reparto porcentual de los libros de historia entre las distintas categorías socio-profesionales:

\begin{tabular}{|l|c|}
\cline { 2 - 2 } \multicolumn{1}{c|}{} & $\%$ \\
\hline Nobleza & 32,5 \\
\hline Funcionariado en general & 26,1 \\
\hline Profesionales de la librería & 17,2 \\
\hline Clero en general & 11,1 \\
\hline Profesiones liberales & 4,4 \\
\hline Indeterminados & 3,3 \\
\hline Servicios Sanitarios & 1,8 \\
\hline Oficios artísticos & 1,5 \\
\hline
\end{tabular}

Hispania, LXV/3, núm. 221 (2005) 877-938 


\begin{tabular}{|l|c|}
\hline Artesanado & 0,8 \\
\hline Servicio doméstico & 0,7 \\
\hline Mercaderes & 0,5 \\
\hline Oficios varios & 0,005 \\
\hline
\end{tabular}

Fuente: Archivo Histórico de Protocolos de Madrid (A.H.P.M.) (Elaboración propia)

\section{LOS LIBROS Y SUS POSEEDORES. LOS CONTENIDOS HISTÓRICOS}

A la hora de estudiar los contenidos históricos cabe entender que nuestra intención no será repasar exhaustivamente el conjunto de libros registrados en los inventarios analizados, pues sería una empresa que desbordaría los límites de este trabajo. Tampoco ejemplificaremos toda la inmensa anchura que ocupa la historia de la historiografía habiendo para ello publicaciones ampliamente documentadas y reconocidas ${ }^{21}$. Tan sólo intentaremos mostrar - sin apartarnos de la línea expositiva que marcan los tres grandes bloques en los que hemos dividido la materia- algunos datos cuantitativos, comparativos y testimoniales que ayuden a conocer la proyección que tuvieron sobre los diferentes espacios socio-profesionales madrileños determinadas tendencias historiográficas, obras y autores.

\section{La historia eclesiástica como construcción espiritual del Imperio}

Con frecuencia la historia se manifestó fiel servidora de la doctrina. De su lectura y aprendizaje cada colectivo social pudo llegar a consolidar una serie de valores espirituales, éticos e históricos que, además, desde un plano personal, guardaban favorecer la afirmación de la propia fe. Sin embargo, bastantes de estas representaciones referidas a la historiografía eclesiástica (vida y obra de pontífices, episcopología en general, relatos acerca del origen e implantación de las órdenes religiosas, entre otras) se escribieron ofreciendo pautas y modelos cuyas deducciones religiosas -en ocasiones planteadas desde una perspectiva apologética y polemista - en muchos casos sólo llegaron a recrear, edificar, o simplemente sorprender al lector ${ }^{22}$.

21 Vid. CEPEDA ADÁN, José: «La Historiografía» en El Siglo del Quijote (1580-1680), I. Historia de España, fundada por R. Menéndez Pidal, dirigida por José María Jover, XXVI, Madrid, pp. 525632; FUETER, Eduardo: Historia de la historiografia moderna, Buenos Aires, 1953; TATE, Robert B.: Ensayos sobre la bistoriografía peninsular del siglo XV, Madrid, 1970. ANDRÉS-GALLEGO, José (coord): Historia de la bistoriografía española, Madrid, 2004. GARCíA CÁRCEL, Ricardo (coord): La construcción de las Historias de España, Madrid, 2004.

22 Algunas reflexiones más en MARTíNEz RuIZ, Enrique et al.: El peso de la Iglesia. Cuatro siglos de órdenes religiosas en España, Madrid, 2004, pp. 552-53.

Hispania, LXV/3, núm. 221 (2005) 877-938 
Es cierto que a pesar de encontrar en no pocas obras planteamientos claramente «medievalizantes» en donde se admitía sobre los designios del hombre la exclusiva validez de la providencia, también es cierto que, sin desdeñar la originalidad y especificidad que representaba el hecho eclesial, la disposición general de estos escritos mantuvo unos propósitos bastante similares a los planteados por la historiografía profana, es decir, unos fines que apuntaron a profundizar en los mismos conceptos tradicionales de definición de los grupos y de las pertenencias, cimientos y principios en los que se afirmaron buena parte de los preceptos sociales y políticos del devenir cotidiano. Como ha señalado José Luis Martín, la presencia casi absoluta de la Iglesia en todas las manifestaciones del hombre no se libró ni pretendió librarse de la realidad histórica que le tocó vivir en cada momento ${ }^{23}$.

En el análisis general de nuestras bibliotecas comprobamos cómo la historiografía referida a la Iglesia presenta unas obras de contenidos bastante monocordes y dirigidos con títulos no demasiado diversificados, pero que, a su vez, despiertan un alto interés de apropiación por parte de la totalidad del arco social de lectores madrileños. Unos comportamientos de posesión que en su conjunto nos anuncian un género literario capaz de mantener una notable continuidad en el tiempo, suficiente afinidad social y un marcado cruce cultural.

Al reinado de Felipe II corresponden algunos de los historiadores con mayor proyección en nuestras bibliotecas. La Historia Pontifical y Católica de Gonzalo de Illescas (impresa en Salamanca en 1574) marcó una época. A juzgar por las frecuentes reimpresiones repetidas en breves intervalos, puede hablarse de rotundo éxito editorial. En verdad, a pesar de haber tenido problemas con la censura inquisitorial ${ }^{24} \mathrm{e}$ incluso algún que otro incidente aislado "por algunas otras cosas que el dicho libro tiene impertinentes» ${ }^{25}$, se trata de un meritorio trabajo rebosante de datos y noticias sobre los distintos pontificados de la Iglesia desde la antigüedad. La amplia selección y el rigor empleados por Illescas en el manejo de las fuentes documentales hicieron de su Historia un repertorio de obligada consulta para cronistas oficiales de su tiempo incluso para autores posteriores ${ }^{26}$.

La sociedad madrileña, en su más amplio espectro, manifestó una visible preferencia por esta obra desde el preciso momento de su publicación. Efectivamente, disponemos de abundantes testimonios que confirman su alta divul-

23 MARTín RoDRíGUEZ, José Luis: «Iglesia y vida religiosa», en La bistoria medieval en España. Un balance bistoriográfico (1968-1998), Pamplona, 1999, pp. 431-456.

24 GACTO, Enrique: «Censura política e Inquisición: La Historia Pontifical de Gonzalo de Illescas", en Revista de la Inquisición, 2, (1992), pp. 23-40.

25 Así se califica en la «Copia de minuta de la carta de Su Majestad a Guzmán de Silva, fecha en Aranjuez a 23 de mayo de 1568", en CODOIN, tomo XC, pp. 70-71.

26 Sabemos, por ejemplo, que Saavedra Fajardo se sirvió de ella para documentar su Corona gótica, castellana y austriaca (1645). 
gación: Íñigo Cárdenas Zapata, presidente del consejo de Órdenes (1585) ${ }^{27}$; Pedro Rodríguez de Alcántara, regidor de Madrid (1596); Francisco de Oseguera, alguacil de la Inquisición (1599); el familiar del Santo Oficio Juan Martínez Cortejudo (1600); la viuda Juana de Mújica y Butrón (1617); Francisco Ruiz de Ondárroa, ayuda de guardajoyas real (1629) y Agustín Valverde, guadarnés del rey (1644), eran algunos de los que poseían en el momento de su muerte ejemplares de la obra de Illescas. También estuvo entre los libros de los cordoneros Cristóbal del Castillo (1589), Bernabé del Vado (1628) y Manuel de Ayllón (1631), y, asimismo, entre los de los plateros de oro Bernardino de Villafranca (1611) y Francisco Gutiérrez (1633). Una «Historia de Illescas» formó parte de los libros del mercader en sebo y tocino Juan Caballero (1592), y hasta tres ejemplares se anotaron en el inventario de la biblioteca del contador Juan de Aguiar (1634).

Por su parte, los fondos de algunos negocios de librería madrileños muestran también el impacto editorial de la obra: en el establecimiento de la calle de Santiago del librero de origen flamenco Juan Hasrey (1615) ${ }^{28}$ encontramos, junto a algunas copias bien encuadernadas y listas para su venta al precio de ocho reales la unidad, una importante partida en papel compuesta por 663 «Historia Pontifical» valoradas en la respetable cantidad de 1.180 reales.

Contemporánea a la obra de Illescas y con similares pretensiones de historia universal fue la escrita por fray Juan de Pineda: Monarquía eclesiástica o Historia universal del mundo (Salamanca, 1588). Se trata de una descomunal compilación narrada con un estilo laudatorio y de escasa aplicación sistemática en donde, a veces, sin criterio aparente se mezclan datos sobre diferentes asuntos eclesiásticos relativos a diversas naciones desde los primeros tiempos de la creación del mundo, con otros actuales de la política de esos mismos territorios. Asegura Sánchez Alonso «que hubiera sido un excelente ejemplar de historia universal si el autor hubiera tenido algún sentido crítico, pues pocos habrán puesto un esfuerzo tan serio en lograr una exposición ininterrumpida del pasado humano" ${ }^{29}$. La difusión de la obra de Pineda, al igual que la de Illescas, concentró en Madrid a un numeroso y heterogéneo mercado de lectores que, empero de su año de edición, se condensó entre titulares de inventarios de la primera mitad del XVII: de las 81 referencias halladas en los 73 repertorios contabilizados, el 87 por ciento corresponde a inventarios fechados entre 1601 a 1650 .

El compendio de Pineda lo hallamos entre los escogidos libros del poeta y militar madrileño Alonso de Ercilla y Zúñiga (1594). Y compartiendo anaquel con la obra de Illescas lo vemos formar parte de las modestas bibliotecas del

27 Para cotejar las referencias al número de protocolo en donde aparecen los inventarios correspondientes a los distintos titulares citados, vid. PRIETO BeRNABÉ, José Manuel: Lectura y lectores... op. cit., vol. II, pp. 582-605.

28 Juan Haz de Rey es el nombre que aparece en la documentación consultada.

29 SÁNCHEZ AlONSO, Benito: Historia de la historiografía española. Ensayo de un examen de conjunto, vol. II, (de Ocampo a Solís), Madrid, 1944, p. 87.

Hispania, LXV/3, núm. 221 (2005) 877-938 
boticario Francisco Frutos (1628) y de la viuda doña Jerónima de Ocampo y Luna (1643), así como en la distinguida colección del consejero real Lorenzo Polo (1611). Una primera parte de la Monarquía, encuadernada en cuatro tomos, propiedad del escribano de Su Mag. Miguel Rodríguez (1634) fue tasada en 66 reales y, posteriormente, adquirida en la almoneda celebrada en la plazuela de Santa Cruz por Diego Benítez, pagando por ella, junto con otro lote de libros, un total de 198 reales. El también escribano real Juan Bautista Manzano (1630) conservó en la biblioteca de su estudio hasta dos ejemplares.

Al inventariar los libros del médico Luis de Rivera (1608) se anotaron cuatro cuerpos de la Monarquía que, a su vez, compartían anaquel con un ejemplar no identificado intitulado: «De los Pontífices», y con otro de Bartolomeo Sacchi (más conocido como Il Platina): Historia... de vitis ac gestis Summorum Pontificum Romanorum... (Coloniae, 1540). Con respecto a esta obra, aunque no tuvo la resonancia que la de Pineda, sí halló espacio preferente en los grupos culturalmente mejor preparados de la ciudad: el maestro Pedro de la Barreda (1578) era propietario de la citada edición de Colonia de 1540; el capellán real Oliverio Danis tuvo ocasión de leerla en francés, y el presbítero Miguel Suárez Pereyra (1636) en italiano. Tampoco pasó desapercibida para los servidores reales Gabriel de Zayas (1592) y Agustín Álvarez de Toledo (1601).

Desde el punto de vista comercial, sólo añadir que la obra de Pineda estaba a la venta al precio de veinte reales en la tienda del mencionado Hasrey (1615). Una sola copia hallamos expuesta en uno de los diversos cajones libreros que Baltasar Gutiérrez tenía instalados en uno de los patios del Alcázar de los Austrias ${ }^{30}$.

Otras historias circunscritas al ámbito nacional, y, sin embargo, con una proyección mucho más discreta que las dos anteriores, fueron la Historias eclesiásticas y seculares de Aragón de Vicente Blasco de Lanuzza (Zaragoza, 1619), o la Curia eclesiástica... de Francisco Ortiz de Salcedo, editada, esta última, en Madrid por Luis Sánchez en 1610, y que descubrimos en nueve bibliotecas: entre ellas, la especializada del licenciado del consejo de Su Mag. Gaspar de Vallejo (1623), la del agente de negocios Miguel López de Olivares (1631) y la de Francisco Moreno, guantero de la reina (1627), que, a su vez, disponía de la mucho menos frecuentada Historia eclesiástica tripartita... de Magno Aurelio Casiodoro, editada en París en 1493. En esa misma línea cabría mencionar el Teatro eclesiástico de la Santa Iglesia de Oviedo de Gil González Dávila (Madrid, 1635) que localizamos casi de forma exclusiva en la selecta biblioteca del marqués de Campotéjar Pedro de Granada (1643). De uso restringido como la anterior encontramos la Historiae ecclesiasticae de Eusebio de Cesárea (Lovaina, 1569) en donde se narra la primitiva historia de la Iglesia desde el inicio del cristianismo. De ella tan sólo tenemos noticias

30 A.H.P.M., protocolo 940, (1577-X-22). Más datos sobre este librero madrileño en: DE LA Campa, Mariano; Gavela, Delia; MONTERo Reguera, Lola.: «El mundo del libro desde las escrituras públicas notariales: Baltasar Gutiérrez», en Edad de Oro, XVII (1998), pp. 9-17. Sobre la instalación de estos cajones de libros en el patio de la Reina del Alcázar: Moll, Jaime: «Escritores y editores en el Madrid de los Austrias», en Edad de Oro, XVII (198), p. 103. 
en las bibliotecas del licenciado Juan Ochoa de Madariaga (1642), y en la del almirante de Castilla Juan Alfonso Enríquez (1647).

Ciertamente, cualquier nueva historia relativa a la Iglesia fue capaz de encontrar el más plural abanico lector dentro del contorno urbano madrileño. Tal vez una de las más denotadas fue la Historia eclesiástica del Scisma del Reino de Inglaterra publicada en Madrid en 1589 por la viuda de Alonso Gómez, y en la que su autor Pedro de Ribadeneyra airea su más apasionado subjetivismo por la causa católica al relatar las persecuciones sufridas por los papistas durante los reinados de Enrique VIII e Isabel I. Sin duda, la irrevocable orientación conducionista que le dio el jesuita lanzó a la obra hacia un extraordinario logro editorial disfrutando de una nutrida continuidad más allá de la última década del siglo XVI, así como entre la mayoría de los espacios lectores de la sociedad, no precisamente de mayoría eclesiástica o nobiliaria.

La nómina de poseedores sería larga de detallar, pero quizás a la hora de probar su variada adscripción social y dilatada proyección cronológica bastaría con citar cinco casos concretos suficientemente alejados en el tiempo: el del secretario real Gabriel de Zayas (1592), el del familiar del Santo Oficio Juan Martínez de Cortejudo (1600), el de Ana de Manrique, condesa de Puñoenrrostro (1616), el del contador Juan de Aguiar (1634), o el de la viuda Isabel de Aguilera (1647).

Son harto más discretas las cifras de ejemplares que contabilizamos de la obra que sobre el mismo asunto publicó en Madrid en 1599 a cargo de Luis Sánchez, Diego de Yepes: Historia particular de la persecución de Inglaterra. En contraste con la de Ribadeneyra tan sólo tenemos referencias fiables en ocho colecciones, una de ellas en la del guantero de la reina Francisco Moreno (1627). Sin embargo, descubrimos en no pocos inventarios noticias con el ambiguo título de «Historia de Inglaterra» que indistintamente podría corresponderse con la obra de Ribadeneyra, o, tal vez, con la de Yepes. Anotados con estas características hallamos varios asientos en los inventarios de Francisco de Nevares y Santoyo, señor de Carabaña y Valdilecha (1632), del platero de oro Bernardino de Villafranca (1611), de la condesa de Puñoenrrostro Ana Manrique (1616), así como en el del contador Juan de Aguiar (1634).

En este grupo cabe citar la exclusiva entrada que encontramos en la colección del caballero de Santiago Juan de Ayala (1594), intitulada: «De la reyna de Inglaterra fecho de calviniano en las herejías», que identificamos con el anónimo: Elizabethae Angliae Reginae haeresim caluinianam propugnantis... (Augustae, 1592.).

De prestigio podría calificarse la Vida de San Ignacio editada en Madrid por Alonso Gómez en 1583. Un texto de gran pureza clásica y con un profundo calado histórico en el que Ribadeneyra sitúa a Ignacio de Loyola —en palabras de George Lefebvre- como parte activa en el conflicto entre la Iglesia y la herejía, haciendo de su biografía una gran obra histórica ${ }^{31}$. La descubrimos en

31. LEFEBVRE, George: El nacimiento de la historiografía moderna, Barcelona, Martínez Roca ediciones, 1974, p. 91.

Hispania, LXV/3, núm. 221 (2005) 877-938 
29 bibliotecas particulares de la segunda mitad del XVI y en 46 de la primera del XVII: un dato cuantitativo que permite deducir la sólida continuidad de la obra desde el preciso momento de su publicación. Por ejemplo, las seleccionadas colecciones de Jácome de Trezzo, escultor real (1589), de Juan de Para, contador regio (1595), y de Juan de Acuña, marqués del Valle (1616) contaban con la biografía ignaciana. El capiscol Antonio de Borja (1614) era propietario de la edición impresa en Roma en 1587, y Juana de Mújica (1617) tuvo ocasión de leerla en latín. Entre otros conservadores ilustres de este libro estaba el secretario Zayas (1592) con dos ejemplares.

Desde el punto de vista historiográfico, en lo tocante a las órdenes religiosas conviene indicar que, mayoritariamente, se trata de crónicas, relaciones o compendios preferentemente dedicados a encumbrar y celebrar total e unitariamente la historia de al menos media docena de las más significativos institutos religiosos de la época: franciscanos, dominicos, carmelitas, agustinos, jerónimos y jesuitas. Se detecta en la mayoría de sus historias una compleja producción editorial de muy desigual interés y calidad en donde cualquiera de las órdenes citadas o no, lograron un número importante de testimonios impresos en su mayoría con la intención de divulgar su verosímil antigüedad, glorificado pasado y los hechos de sus hombres y mujeres más ilustres, incluso si venía al caso de preservar la propia identidad frente a posibles rivales y demás autoridades religiosas y civiles.

Con lenguaje exacerbado y potente dosis de expresionismo religioso se dieron a la prensa todo tipo de relatos bajo cualquier contexto histórico-cultural -en su mayoría cimentados en representaciones de naturaleza hagiográficay en los que junto al propósito central de profundizar en la espiritualidad cristiana se intentaba llegar a mecanismos de asimilación y de proyección de la memoria colectiva dejando en un segundo plano el rigor estrictamente históri$\mathrm{Co}^{32}$. Como ha señalado Francisco José Aranda, será necesario esperar a las críticas anticlericales del siglo XVIII para encontrar las primeras denuncias contra las arbitrariedades de estas historias eclesiásticas ${ }^{33}$.

Aunque pueda parecer paradójico no fueron los eclesiásticos los principales poseedores de estas obras. Representantes de la mayoría de los grupos alfabetizados madrileños poseyeron una o varias copias de dichas obras, aunque con excepciones relativamente significativas por parte de algunos sectores cultos y profesionalizados como licenciados, abogados o médicos.

32 En opinión de Ofelia Rey: «las falsificaciones históricas fueron fomentadas o consentidas por la jerarquía eclesiástica», asegura que el «fraude piadoso estaba admitido en la moral general como motivo edificante y había numerosos autores que creían lícito falsear la historia cuando el honor de «la patria» lo exigía. Vid. REY CASTELAO, Ofelia: Libros y lectura en Galicia. Siglos XVI-XIX, Santiago de Compostela, 2003, p. 586.

33 ARANDA PÉREZ, Francisco José: «Autobiografías ciudadanas. Historias, mitomanía y falsificación en el mundo urbano hispánico de la Edad Moderna», en Ernesto García Fernández (ed.): El poder en Europa y América: mitos, tópicos y realidades, Bilbao, Univ. del País Vasco, 2001, p. 155. 
Dos de los títulos más solicitados fueron la Chronica de la orden de frayles Menores conocida también como Crónica de San Francisco, generalmente la escrita por Marcos de Lisboa, y la Crónica de Santo Domingo (casi siempre descrita sin autor) que hallamos en numerosos inventarios sin apenas diferenciaciones porcentuales en los tramos cronológicos analizados. En 108 bibliotecas se han detectado y contado volúmenes de algunas de estas crónicas. Ante este pequeño océano, tal vez lo más sensato era encontrar una biblioteca modelo que ejemplificara la alta difusión de este tipo de literatura, y, ante otros posibles modelos, elegimos la del contador real Juan de Aguiar (1634), en donde se relacionan la "Crónica de San Jerónimo" que identificamos con la publicada en Madrid en 1600 por fray José Sigüenza, pasando por la citada «Crónica de San Francisco», y la «Historia de San Bernardo», probablemente la escrita por fray Bernabé de Montalbo (Madrid, 1602), hasta la menos frecuentada «Historia del patrón de España» de Hernando Ojea (Madrid, 1615).

Como síntesis final habría que hablar de unos comportamientos de posesión bastante progresivos que nos llegan a presentar un tipo de historias que se caracterizan por su amplia receptividad sin apenas distinciones de género, movilidad en el tiempo, afinidad social y confluencia cultural.

\section{La historia civil: vehículo de entidad social y orden político}

Los cambios historiográficos producidos desde aproximadamente el siglo XIII fueron dejando atrás los testimonios narrativos de origen altomedieval. Unos modelos caracterizados por su rigidez, carentes de una clara línea argumental y criterio propio, en los que, desde el concepto territorial de España, por un lado, aspiraban a honrar a Dios y, por otro, quedaban sujetos a la exclusiva razón de legitimar los nuevos órdenes políticos basados en la figura real, siempre bajo el papel determinante y supervisor de la Iglesia ${ }^{34}$.

Los resultados permitieron una transformación paulatina en el llamado nuevo saber de la historia a pesar de que no se renunciara definitivamente a las recreaciones legendarias y a los modelos proféticos. El caso es que se fue conformando un procedimiento historiográfico a través del reflejo de la antigüedad clásica, pero en el que aún prevalecieron - dentro de las nuevas condiciones políticas y transformaciones sociales - Ios ideales de fortalecimiento del poder establecido, la preparación de un nuevo orden político con claras aspiraciones imperiales, y con ellos, una marcada determinación a la hora de buscar imágenes y horizontes a escala nacional y universal.

Como cabría esperar, un variado y amplísimo proceso historiográfico que alcanzó desde la producción grecolatina y medieval hasta la renacentista y ba-

34 Cfr. FontanA, Josep: Historia: análisis del pasado y proyecto social, Barcelona, Ed. Crítica, 1982, pp. 31-40.

Hispania, LXV/3, núm. 221 (2005) 877-938 
rroca, y que se fue instalando en la España de los siglos áureos constituyendo un eficaz medio para reforzar esa idea de estado-nación como proyecto colectivo. Un propósito socialmente encauzado a satisfacer el afán de búsqueda, divulgación, justificación, comprensión y disfrute de unos hechos pasados o presentes dentro del cada vez más holgado público dispuesto y capaz de acceder como autores, editores o simples receptores ${ }^{35}$.

La proliferación de las grandes obras maestras de la historiografía grecolatina, y su conocimiento "popular» de nuevo tuvieron como principal valedor a la imprenta. Por su parte, los modelos propuestos por el Humanismo, interesado en demostrar la gran trascendencia de la historia, se legitimaron acudiendo a los textos de la antigüedad clásica. De ahí que, desde los orígenes del Renacimiento, los autores latinos y griegos se fueran confirmando en el paradigma del espíritu crítico, en la voz de la experiencia y en la esencia del pragmatismo que asignaba a la denominada magistra vitae el absoluto provecho moral de utilizar en beneficio universal los dechados del pasado. Sabemos, por ejemplo, que para Tito Livio el pasado era digno de remembranza porque siempre servía de modelo, bien de las virtudes dignas de imitarse, bien de los errores que debían evitarse ${ }^{36}$.

La cuestión concernía ahora a la recuperación gradual del género historiográfico que fue creando una renovada formación en la opinión de muchos lectores y autores, siempre marcada por la exigencia en la selección, interpretación y asimilación de los hechos. Las mismas traducciones propiciadas por la tipografía además de permitir superar la barrera del latín y del griego condujeron a la universalización, reactualización y equiparación que proponían algunos modelos clásicos. Conocemos por distintas referencias, por ejemplo, que la lectura de Julio César fue largamente exhortada entre los círculos intelectuales de la España del Quinientos, y, al menos sus Comentarios se mostraron, principalmente, como prototipo a la hora de escribir historia. De forma similar, la claridad y sencillez de las enseñanzas habidas en las obras de Quinto Curcio fueron exteriorizadas - a modo de lectura recomendada para jóvenes nobles y príncipes- por autores como Justo Lipsio ${ }^{37}$. Similar intención demostró Juan Martín

35 Estas ideas pueden verse en WULFF, Fernando: Las esencias patrias. Historiografia e Historia antigua en la construcción de la identidad española (siglos XVI-XX), Barcelona, Crítica, 2003, pp. 15-20.

36 Vid. CODOÑER, Carmen: "Un modelo imitativo: la historiografía latina», en Stvdia Historica. Historia Moderna, vol. XIII (1995), p. 26.

37 Sobre la enseñanza y experiencia que aportaban las lecciones de historia, especialmente, para el príncipe, vid. MONTERO DíAZ, Santiago: «La doctrina de la historia en los tratadistas españoles del Siglo de Oro", Hispania, I, (1941), IV, pp. 3-39. En concreto para el programa pedagógico basado en lecturas recomendadas que llevó el príncipe don Carlos, hijo de Felipe II, en GoNZALO SÁNCHEZ-MOLERO, José Luis: "Lectura y bibliofilia en el príncipe don Carlos (1545-1568), o la alucinada búsqueda de la «sabiduría», en Pedro M. Cátedra y María Luisa López-Vidriero (dirs.): La memoria de los libros. Estudios sobre la historia del escrito y de la lectura en Europa y América, Salamanca, (HILL), 2 vols., I, pp. 705-734. 
Cordero al dedicar a Felipe II su traducción de la obra de Flavio Josefo: Las guerras de los judíos y la destrucción de Hierusalem (Amberes, 1557). Las propias res gestae descritas por Plutarco en sus Vidas paralelas se equipararon en el prólogo a la traducción de Francisco de Enzinas (1551) con las hazañas bélicas de Carlos $\mathrm{V}^{38}$. Otro ejemplo, de los muchos posibles, sería el aportado por Jaime Bartolomé, canónigo de la Seu de Urgell, traductor de la Historia de las guerras civiles de los romanos (Barcelona, 1592) de Apiano Alejandrino. En el momento de redactar el correspondiente prólogo no dudó en llamar la atención acerca del paralelismo que él veía entre la pérdida de la reputación y gloria de Roma - al iniciarse las disensiones de la época de Cayo Graco- con las alteraciones de Aragón en tiempos del Rey Católico ${ }^{39}$. Como puede advertirse el propósito no era otro que llegar a ofrecer una visión esencial y ejemplarizante de los acontecimientos presentes tomando como base de inspiración los modelos narrativos de las grandes obras del pasado.

La composición temática global de las bibliotecas madrileñas refleja una coherencia marcada por el signo de la variedad de autores y obras, en donde, sin embargo, el equilibrio se rompe claramente a favor de la historiografía latina. Una tendencia que se muestra de forma algo más nítida en la segunda mitad del siglo XVI que durante los siguientes cincuenta años.

En relación con los grupos socio-profesionales instalados en la ciudad, la nobleza, el funcionariado en general, el alto clero, intelectuales de todo tipo y profesiones liberales, (esencialmente juristas) son los principales poseedores de las principales obras de los principales historiadores clásicos: Valerio Máximo, Julio César, Quinto Curcio, Tito Livio, Salustio, Suetonio, Tácito, Flavio Josefo, o Apiano Alejandrino, etc. Por su parte, la historiografía griega - exceptuando a Tucídides y Plutarco- se muestra en un plano de divulgación mucho más secundario: Polibio, Homero, Herodoto, Diodoro Sículo, Jenofonte, etc., sólo llegan a representar el 18 por ciento de la nómina total de historiadores clásicos hallados en nuestras bibliotecas. Algunos casos concretos como Ptolomeo o Pomponio Mela rompen estas proporciones al alza.

$\mathrm{El}$ interés por este género, como adelantábamos, se mostró en las bibliotecas particulares y librerías madrileñas de la segunda mitad del siglo XVI de forma algo más resuelta que en las del XVII. Frente a un 3,6 por ciento de media entre 1550 y 1600 se baja hasta el 2,9 durante la primera mitad del siglo XVII.

Dado el amplísimo entramado de inventarios en el que nos movemos, la vanguardia intelectual singularizada por los grupos mejor alfabetizados y con

38 Sobre la influencia de Plutarco en España véase el trabajo de PÉreZ Jiménez, Aurelio: «Plutarco y el Humanismo español del Renacimiento", en Estudios sobre Plutarco: obra y tradición. Actas del I Simposio Español sobre Plutarco (Fuengirola 1988), Málaga, 1990.

39 Vid. ESPINO LÓPEZ, Antonio: Guerra y cultura en la época moderna, Madrid, Ministerio de Defensa, 2001, en especial el capítulo tercero: «Clio y Marte. El aprendizaje de la guerra a través de las obras de historia», p. 167.

Hispania, LXV/3, núm. 221 (2005) 877-938 
mayores posibilidades para adquirir libros no oculta, sin embargo, la otra gran realidad representada por los oficios artísticos, el sector del comercio y el artesanado que muestran unos índices más que aceptables en la posesión de este tipo de historiografía. Valga el ejemplo de la mencionada biblioteca del escultor Jácome de Trezzo (1589) en la que se relacionan dos Tito Livio: Historiae y Décadas, la Geographia de Ptolomeo, un Flavio Josefo: Guerra de los judíos, más un ejemplar de Bello Púnico de Polibio. Igualmente, al inventariar los bienes del platero de oro Alonso Carrión (1609) se hallaron unas Historias romanas de Valerio Máximo, la Historia de Alejandro Magno de Quinto Curcio y un «Salustio». También el boticario Diego de Cortavila (1615) poseía en el momento de su fallecimiento un «Herodoto» y una «Destrucción de Troya», que, tal vez hiciera mención a alguna edición latina de los textos de Dares Frigio: De excidio Troiae historia, o de Dictes de Creta: De Historia belli troiani. Citada como «Historia troyana» también tenían ejemplares el médico Esteban de Salvatierra (1581), el contador Alonso Ruiz de Valdivieso (1607), don Fernando de Eraso (1606) y doña Brianda de la Cerda y Sarmiento, duquesa de Béjar (1602).

Volviendo al ejemplo de Julio César, durante la segunda mitad del siglo XVI le hallamos presente en 73 inventarios. Las numerosas ediciones de los Comentarios a las guerras civiles contra Pompeyo y a las libradas en las Galias, a veces en latín e italiano y las más en castellano traducidas por Diego López de Toledo, las encontramos en una amplísima heterogeneidad de colecciones siendo una vez más su principal grupo receptor, la nobleza. Contrariamente, llama la atención la relativa falta de interés por parte del clero en general: es significativo que de esos 73 recuentos tan sólo aparezca citado dicho autor en once ocasiones, en su mayoría en inventarios pertenecientes a representantes del alto clero. Una pequeña nómina de poseedores madrileños con bibliotecas fechadas durante este periodo sería la siguiente: Hernando Lucero, criado del rey (1579); Antonio Eguino (1580) con dos ejemplares, uno de ellos en lengua «toscana»; el secretario Miguel Ruiz de Azagra (1583); el regidor Melén Suárez de Solís (1591), o Fadrique Furió Ceriol, gentilhombre de la casa del rey (1592). Por el contrario, durante el periodo 1600-1650 aunque el número de referencias a Julio César se mantuvo en términos absolutos, tal vez un más diseminado interés ciudadano por poseer esencialmente sus Comentarios (principalmente por parte de los estratos menos favorecidos de la sociedad) permite considerar una cierta sensación de pluralidad, aunque la mayor difusión siguió corriendo a cargo de nobles como Juan Fernández de Velasco, condestable de Castilla (1608), Pedro de Granada, marqués de Campotéjar (1643), el caballero de Santiago Juan de Santa Cruz (1644), Juan Alfonso Enríquez de Cabrera, almirante de Castilla (1647) o Antonio de Orlandis, del consejo de Su Mag. (1620).

Como muestra de una semejante divulgación y relativa estabilidad cronológica es necesario aludir, además, a la figura de Valerio Máximo y a sus famosos Hechos y dichos memorables. Una obra portadora de un gran contenido pedagógico que pudo ayudar a fijar las virtudes morales y otras rectas costumbres en el madrileño de la época. Como hemos indicado, no es nuestro propósito 
relacionar la extensa nómina de propietarios de este autor, pero tal vez valdría constatar que le hemos localizado en 45 repertorios entre 1550 y 1600 y en 33 entre 1601 y 1650 , eso sí, en la mayoría de las ocasiones aludiendo exclusivamente a su nombre, sin referencia a ninguno de sus títulos. Estas elementales comparaciones no tienen otro objetivo que mostrar el ligero repliegue que sufrió la obra, no así entre los círculos de la minoría intelectual de la ciudad. No obstante, aún es posible hacerse una idea de la general difusión que tuvo este autor durante la primera mitad del Seiscientos a través de los fondos de algunos negocios de librería como el regentado por Sebastián de Robles (1612), en las covachuelas de la calle del Estudio, junto al Rastro, en donde encontramos dos «Valerio Máximo», encuadernados, al precio de cinco reales la unidad ${ }^{40}$. En los anaqueles de la tienda de su colega Antonio Rodríguez (1623) instalada en la calle de Santiago, se hallaron, aún sin vender, 24 ejemplares, a real cada uno. Y, también en papel, en la librería de Juan Hasrey (1615), estaban depositadas 151 copias, en dieciseisavo, a real la unidad, más otras 80 , en octavo, a dos reales.

Otras aportaciones historiográficas de similar eco lector y largo proceso de permanencia fueron las Décadas de Tito Livio, y los Anales de Cornelio Tácito. Sin ningún tipo de relación automática, los poseedores de los escritos de estos autores se reparten entre todo el abanico social de la ciudad, aunque como es natural con algunas diferencias porcentuales a favor de los grupos privilegiados. El comendador Juan Enríquez de Guzmán (1591) atesoraba dos ejemplares de las Décadas de Livio. Con igual número, la descubrimos en la biblioteca de Fadrique Furió que, a su vez, se complementaba con tres copias de las obras de Julio César, y con una de las de Tácito, Apiano Alejandrino, Plutarco y Polibio. El presidente del consejo de Indias, Juan de Ovando (1575), junto a los ejemplares de Tito Livio o Valerio Máximo tuvo ocasión de poder leer un interesante «Cayo Silio Itálico» posiblemente su De Bello Punico, editada en Florencia en $1515^{41}$. El también noble Pedro de Granada (1643) dejó tras su fallecimiento cuatro ejemplares de las obras de Tácito: un par sin especificar y otros dos traducidos en romance, uno por Emanuel Sueyro (Madrid, 1614), el otro por Antonio de Herrera (Madrid, 1615).

En 1608, en el inventario de la selecta biblioteca del médico Luis de Rivera se anotó la Historia de la guerra del Peloponeso de Tucídides, en latín, y con ella tres "Quinto Curcio», dos «Jenofonte», dos "Valerio Máximo», más un ejemplar de

\footnotetext{
40 El inventario de este librero madrileño fue estudiado por PELIGRY, Christian: «El inventario de Sebastián de Robles, librero madrileño del siglo XVII», en Cuadernos Bibliográficos, 32 (1975), pp. 181188. De éste, y de otros muchos libreros madrileños de los siglos XVI y XVII, vid. MOLL, Jaime: «Escritores y editores...» op. cit., pp. 97-106. DELGADO CASADO, Juan: Diccionario de impresores españoles (siglos XV-XVII), 2 vols., Madrid, 1996. AGUlLó COBO, Mercedes: «Noticias de impresores y libreros madrileños de los siglos XVI y XVII» en Anales del Instituto de Estudios Madrileños, II (1967) p. 191.

${ }^{41}$ Un interesante análisis de esta biblioteca en BOUZA ÁlVAREZ, Fernando J. y ALVAR EZQUERRA, Alfredo: «Apuntes biográficos y análisis de la biblioteca de un gran estadista hispano del siglo XVI: el presidente Juan de Ovando", en Revista de Indias, 1984, XLIV, 173, pp. 81-139.
} 
las obras de «Plucharco», «Tito Livio», «Tolomeo» $\mathrm{y}$ «Apiano Alexandrino». Descubrimos una distorsionada entrada en el inventario del secretario real Gabriel de Zayas (1592) descrita como: «Bala sobre tuçides» que identificamos con la obra de Lorenzo Valla: Thucydidis Atheniensis... de Bello Pelopones (Paris, 1513).

A pesar de las habituales referencias incompletas con las que tropezamos en la mayoría de los recuentos analizados, en el caso concreto de la historiografía grecolatina es posible concluir señalando que al menos en tres de cada diez inventarios aparece alguna obra del selecto grupo de autores compuesto por Julio César, Valerio Máximo, Tito Livio, Quinto Curcio, Salustio, Apiano Alejandrino, Tucídides, Mela, Ptolomeo o Plutarco. De igual modo, podemos añadir que de todo el periodo estudiado (en torno al 70 por ciento de los registros identificados), corresponde a historiadores latinos, siendo los círculos lectores más proclives a mantener la memoria de la historiografía grecolatina los formados por los grupos estamentales, y, en general, por la minoría culta de la ciudad.

Otras referencias significativas de la literatura histórica -en este caso castellana- que interesaron en nuestra ciudad fueron las crónicas medievales de origen cristiano.

Resulta casi natural que las obras con anterioridad escritas a las de Alfonso $\mathrm{X}$ el Sabio no se manifiesten de manera palmaria en nuestras bibliotecas, aunque algunos valores hallados - desde la relatividad de las cifras- pueden calificarse de significativos. Ya desde el siglo XIII, cronistas como Rodrigo Jiménez de Rada ${ }^{42}$ ponen y plantean buena parte de las bases de lo que sería la historiografía moderna. Con el Toledano, junto a otros autores como el obispo Lucas de Tuy, se comienza a valorar la documentación conservada en archivos reales y monásticos, y desde la conformidad a los preceptos clásicos se obligan a participar como testigos oculares, o al menos como conocedores directos de los lugares en donde se decidieron los acontecimientos objeto de estudio. No se deja fuente documental sin confrontar, y su aplicación práctica deriva hacia métodos de trabajo mucho más íntegros y sistematizados. Los mismos resultados narrativos, llenos de matices, siempre intentaban aderezarse con relatos poco afectados y con un lenguaje asequible, todo ello sin apartarse de las causas profundas de los hechos y del sentido de permanencia de la memoria histórica. En el caso de la obra de Rada: Historia Gótica muestra inmejorablemente ese modo de historiar que prepararía el terreno a posteriores compilaciones $^{43}$. como las auspiciadas por Alfonso X el Sabio.

42 La cronística medieval española puede seguirse a través del ya clásico trabajo de TATE, Robert B.: Ensayos sobre la bistoriografía peninsular... op. cit., y los de MITRE, Emilio: «¿Un sentimiento de comunidad hispánica? La historiografía peninsular» en Historia de España fundada por Ramón Menéndez Pidal, XVI, pp. 409-434; y LóPEZ-VIDRIERO, María Luisa: «Les chroniques imprimées: livre de Cour dans l'Espagne du XVIe siècle», en Amedeo Quondam (edt): Il libro a Corte, Roma, 1994, pp. 401 y ss..

43 Una autoridad que no sólo influyó en la posterior tradición historiográfica medieval castellana, sino, como ha advertido Manuel Peña, también en la de origen catalán. Vid. PEÑA DíAZ, Manuel: El laberinto de los libros... op. cit., p. 109. 
Nos encontramos, en líneas generales, ante unos textos tenazmente marcados por la idea de exhumar un espíritu colectivo y fusionado del pasado histórico español, más bien castellano-leonés ${ }^{44}$. Y así se manifestó, al menos, en una de las grandes obras que más reconocimiento tuvo en los anaqueles de los madrileños: la Primera Crónica General de España ${ }^{45}$ y que encontramos en un número significativo de colecciones madrileñas de la segunda mitad del XVI, aminorando su posesión durante las siguientes cinco décadas. ¿Quiénes fueron sus principales poseedores? La cantidad es también aquí el primer elemento que permite distinguir la recepción y continuidad de la obra. Por ejemplo, descontando las muchas citas imprecisas y ambiguas tales como: «Crónica General de España», muy fáciles de ver en inventarios de todo tipo y condición como los del platero Rodrigo Inojal (1588) y el clérigo Alonso Cedillo (1627). Hay otro rosario de menciones de similar naturaleza que agrandan la fractura de la desinformación: una «Crónica vieja de España, de letra antigua» hallamos en las colecciones de Diego de la Torre (1599) y Mariana de Montaña (1630). Incluso, aparecen alusiones aún más insistentes como "Crónica de España» que igualmente rescatamos de múltiples recuentos, entre otros, los del clérigo Fernando de León (1599), Álvaro de Córdoba (1602), Francisco Arias Dávila, conde de Puñoenrostro (1610), Alonso Páez, pintor artístico (1612) o Miguel de Arizu, cantor de la Real Capilla (1648) y que, obviamente, de forma indistinta bien podrían referirse a obras de autores como Ambrosio de Morales, Diego de Valera, Florián de Ocampo o Pedro Antonio Beuter.

Por el contrario, sabemos, con total seguridad, por citarse correctamente en cada inventario, que en el primer periodo analizado (1550-1600) se nos muestra la obra de Alfonso X en 15 recuentos de titularidad nobiliaria, en nueve del alto funcionariado y en tan sólo ocho del clero, licenciados y profesiones sanitarias, sumando cuatro en el resto de grupos. Y como señalábamos, bajan en términos absolutos el número de referencias durante la primera mitad del siglo XVII: tan sólo 19 registros, pero, curiosamente, afectando de manera similar y proporcional a la mayoría de los grupos anteriormente citados, a excepción de nobles y altos funcionarios. Entre los primeros de estos últimos poseían la obra: Juan Fernández de Velasco, duque de Frías (1608), Juan de Acuña (1616), Juan Hurtado de Mendoza y de la Vega (1624), y Alvaro de Bazán, marqués de Santa Cruz (1645). La edición impresa en Valladolid de 1554 la encontramos citada en la distinguida biblioteca del marqués de Campotéjar Pedro de Granada (1643). Dos ejemplares de la edición compuesta en Zamora en 1541

44 Vid. ORCÁstegUI, Carmen y SARASA, Esteban: La historia en la Edad Media. Historiografía e bistoriadores en Europa Occidental: siglos V-XIII, Madrid, Cátedra, 1991, pp. 227-228.

45 Sobre el modelo historiográfico de Alfonso X el Sabio y sus antecedentes puede consultarse la obra colectiva: Alfonso X el Sabio y las crónicas de España, al cuidado de Inés Fernández-Ordóñez, Valladolid, 2000. En esa misma línea es imprescindible: MARTIN, Georges: "Alphonse X et le pouvoir historiographique», en Jean-Philippe Genet (ed.), L'bistorie et les nouveaux publics dans l'Europe médiévale (XIIIe-XVe siècles), Paris, 1997, pp. 229-241. 
bajo el cuidado del cronista oficial de Carlos V Florián de Ocampo, la hallamos entre los libros que recibió en concepto de dote Elvira Dulce Forzela (1600). Y designada textualmente como "Crónica del rey don Alonso el Sabio» la encontramos formando parte de los escasos libros de Antonio de Eguino (1580), del contador Pedro Illán de Liébana (1594) y del médico del rey Juan Simón de Álava e Ibarra (1595), además del marqués de Villanueva del Río, Fernando Enríquez de Rivera (1599) y del ayuda de guardajoyas real Francisco Ruiz de Ondárroa (1629). Una «Crónica del rey Alonso, el de las Partidas» (así citada) se anotó en el inventario de Ana Salcedo (1611). Y como complemento, sólo mencionar el manuscrito, no identificado, propiedad del secretario Ruiz Azagra (1583) intitulado: «Un libro de mano, muy antiguo, ejemplar que es la Corónica de España desde Noé hasta el conde Fernán González».

En la tienda de librería frente a la iglesia de San Felipe regentada por Mariana Hernández (1607), viuda del librero Pedro de la Torre, se almacenaban cinco volúmenes de la "Chronica general de España, de vocablos antiguos» a trece reales el ejemplar. En la instalada en la calle Mayor, junto al Correo mayor, propiedad de Jusepe Vidarte y Errazquin (1624) se tasaron en 20 reales la unidad cinco copias descritas como: «Historia de España que mandó recopilar el rey don Alonso el Sabio con botoncillos», y tan sólo dos en la de su colega Cristóbal López (1606).

La idea de España, identificada como un gran reino de reinos capaz de llegar a la unificación de los distintos pueblos de su territorio, tomó carta de naturaleza gracias al concurso de la imprenta y al de la propia definición de la historia. Justamente, un substancial desarrollo editorial y una sostenida demanda lectora supieron manifestarse en nuestro país desde los primeros pasos de la industria tipográfica. $Y$, naturalmente, la variada cronística de origen medieval, principalmente la referida a la corona de Castilla, se convertiría en la figura esencial de esa exaltación historiográfica de sus antigüedades.

Estamos ante un estilo de historiar que a partir de la ponderación a los valores de mitificación de los monarcas y el de sus respectivos programas políticos seguiría, no obstante, articulándose de acuerdo con los generales esquemas de lectura de tipo práctico y moralizante. Un panorama épico-histórico que se plasmó en numerosas impresiones de obras de muy distinta consideración histórica y valor literario referidas a intensos y extensos reinados medievales: Crónica del Sancto Rey don Fernando Tercero (Sevilla, 1526); Crónica del serenísimo rey Don Juan el Segundo, (Logroño, 1517); Crónica del inclito emperador de España don Alonso VII (Madrid, 1600); Chronica del muy esclarecido Príncipe e Rey don Alfonso el onzeno (Valladolid, 1551), o Crónica del Rey don Rodrigo con la destruyción de España y cómo los moros la ganaron, (Valladolid, 1527.). En esta relación cabrían otros relatos como la Crónica del rey don Pedro, (Toledo, 1526) escrita por el canciller López de Ayala, testigo privilegiado de la Castilla fratricida de la segunda mitad del siglo XIV, y la anónima Coronica de don Álvaro de Luna, condestable de Castilla, atribuida por algunos especialistas a Gonzalo Chacón, e impre- 
sa en Milán en 1546. Todas ellas, a excepción, quizás, de esta última, fueron lectura de mayorías en la ciudad de Madrid.

A finales del siglo XVI, incluso bien entrado el siglo XVII, todavía circulaban innumerables versiones manuscritas: valga como ejemplo la «Crónica del rey don Enrique» que descubrimos entre los libros de Mariana Correa (1588). En ese mismo año, también el teniente de acemilero mayor del rey Pedro de Lira pudo leer una "Crónica del rey don Sancho, escrita de mano", y hasta cinco versiones manuscritas contabilizamos en el inventario de capital de Adrián Calvete (1612), a saber: la «Crónica de don Álvaro de Luna», la «Crónica del rey Enrique III», y hasta tres ejemplares de la famosa «Crónica de Enrique IV». De esta última, la escrita por el licenciado Diego Enríquez del Castillo, la encontramos entre los bienes del regidor de Madrid Pedro Rodríguez de Alcántara (1596), así como en los de Bernardo Slisnequer, agente de los Fúcares (1612) y Gonzalo de Peña Carrillo, capellán real (1620), además de los caballeros de Santiago Gaspar de Vallejo Alderete (1623) y Juan de Castañeda y Ronquillo (1628).

La nómina de los repertorios bibliográficos en los que hemos hallado referencias concretas a una u otra crónica es amplísima y, por tanto, no tendría sentido relacionar esos 112 titulares de inventario. Tal vez sirva mejor subrayar el arraigado aprecio de la nobleza por este tipo de literatura al demostrar una elevada media de 3,3 ejemplares por biblioteca. Por su parte, los funcionarios (en particular los altos servidores del rey) y profesiones liberales alcanzan una media de 2,1 libros, mientras que el estamento eclesiástico tanto sólo llega a 0,6 , y el sector de los mercaderes y artesanos, incluido los oficios artísticos, a la no nimia cifra de 0,9 libros por biblioteca. Algunas bibliotecas tomadas al azar: las de los nobles Álvaro de Córdoba (1602), Hurtado de Mendoza y de la Vega (1624), Mariana de Zúñiga (1628); Pedro de Granada (1643) y Juan Alfonso Enríquez (1647), junto a las de otros ciudadanos más o menos anónimos como Marçiel González, del consejo de Su Mag. (1624), Francisco Ruiz de Ondárroa, ayuda de guardajoyas del rey (1629), Daniel Rutínez, guardarropa del duque de Lerma (1609), de escribanos como Miguel Rodríguez (1634) y Juan Cortés de la Cruz (1651), y de los contadores como Pedro Illán de Liébana (1594), Alonso Ruiz de Valdivieso (1607), y Juan de Aguiar (1634), permiten hablar de esa continuidad en el tiempo que llega con valores sobresalientes hasta los años cincuenta del siglo XVII, aunque, ciertamente, este dato no sea óbice para apuntar que el mayor porcentaje de asientos sigue correspondiendo al periodo $1550-1600$ (66 por ciento).

$\mathrm{Al}$ referirnos a la producción historiográfica dedicada a la cronística medieval de origen catalano-aragonés, observamos que los gustos lectores de los madrileños no pueden equipararse con los expuestos anteriormente. Obras singulares de la talla de las Histoires e conquestes dels Reys de Aragò e comtes de Barcelona de Pere Tomic Cauller, compuesta en 1438, o la del archivero de la Corona aragonesa Pere Miquel Carbonell: Chròniques d'Espanya (Barcelona, 1547), se 
prodigaron muy poco, al menos por lo que hemos podido constatar a través de nuestra documentación notarial ${ }^{46}$. Doña Ana de Salcedo (1611), esposa del contralor real Jerónimo de Quincoces, era propietaria de una «Crónica despaña, en catalán» que bien pudo tratarse de la redactada por Carbonell. A su vez, el ya citado marqués de Campotéjar poseyó una Crónica del rey don Jaime, editada en Barcelona en 1562 en «lengua aragonesa». El secretario Miguel Ruiz Azagra, (1583) tenía en su estudio los «Hechos de los Reyes de Aragón, en latín», más otro libro «escrito en catalán, de la nobleza de los reyes godos y condes de Barcelona» que identificamos con la obra de Tomic. Incluso una edición de Zaragoza de 1553 del Libro de los dichos y hechos del rey Alonso de Aragón de Antonio Beccadelli que, igualmente, hallamos entre los libros del médico Luis de Rivera (1608). Tanto el contador Juan de Aguiar (1634) como el cochero de la reina Toribio Fernández de Cañedo (1637) tuvieron ocasión de leer una «Historia de Cataluña» que seguramente hacía referencia a la escrita por Bernardo Desclot, impresa en Barcelona en 1616, mientras que en los fondos de la librería de Mariana Hernández (1607) aparecen cinco «Crónicas de los condes de Barcelona» tasadas a dos reales cada ejemplar.

Pero la obra que indiscutiblemente ganó mayor reconocimiento en Madrid fue la Crónica de rey don Jaime I de Aragón. Sin contar con su interesante contenido historiográfico, es factible pensar que por derivación de su particular estilo autobiográfico, muy del gusto de la época, y al estar redactada - como señala Emilio Mitre- «con la espontaneidad de quien parece estar explicando de palabra más que escribiendo» ${ }^{47}$, la crónica adquiriera una importante notoriedad. Dos ejemplos muy separados en el tiempo los tenemos en las bibliotecas de Miguel Ruiz Azagra (1583) y del mercader portugués Andrés Barreto (1622). Una «Vida del rey don Jaime escrita en latín» era propiedad del escribano del registro del consejo de Aragón Miguel Gobierno (1615), y en la tienda de librería de Juan Hasrey (1615) se vendía la «Cronica del rei don Jayme» a siete reales, encuadernada en formato folio.

Desde el rotundo predominio de la cronística referida al ámbito castellano, concluir en el sentido de que, a tenor del incentivo que supuso la producción editorial madrileña, el reparto por grupos socio-profesionales reflejó una aceptable diversidad, aunque la mayor difusión la siguieron alcanzando los nobles y buena parte de los altos servidores del rey. Sorprende la discreta atención manifestada por los eclesiásticos y profesionales liberales (relativamente menos acusada entre alto clero y juristas), manteniendo valores, comparativamente hablando, bastante más compensados entre mercaderes, oficios artísticos y, algo menos, entre artesanos. Quizás por razones no estrictamente relacionadas

\footnotetext{
46 Sobre la "visión de Cataluña» desde Castilla en los siglos XVI y XVII, vid. BouZA ÁLVAREZ, Fernando J.: «La visión de Cataluña en el pensamiento castellano. Una Cataluña entrevista en libros y memorabilia de cortesanos», en Manuscrits, 15 (1997), pp. 135-147.

47 MITRE, Emilio: «¿Un sentimiento de comunidad hispánica?... op. cit. p. 421.
} 
con el contenido de estas crónicas, pero sí por su fuerte implantación y vinculación socio-cultural, los porcentajes de posesión entre hombres y mujeres mantuvieron unos valores relativamente equiparables ${ }^{48}$.

Con la llegada a España de reconocidos humanistas italianos como Lucio Marineo Sículo y Pedro Mártir de Anglería invitados por personajes con inquietudes intelectuales como don Fadrique Enríquez, almirante de Castilla, y don Iñigo López de Mendoza, conde de Tendilla, respectivamente, se hicieron importantes progresos en los principios del nuevo panorama historiográfico. Unos modelos ya consagrados por otros humanistas italianos, encabezados por Leonardo Bruni, Coluccio Salutati, o Poggio Bracciolini que intentaron enmendar, incluso suprimir completamente cualquier rastro apologético y deformado de la historia que tuviera un origen medieval - ya por otro lado bastante denostado y sin aparente eficacia discursiva - y sustituirlo por uno nuevo que estuviera en permanente diálogo con los métodos propuestos por la antigüedad clásica. En definitiva, junto a la imitación de los modelos grecolatinos y la tendencia de «secularización» de la historia, hay que añadir, según la interpretación de W. K. Ferguson, tres nuevas cualidades: interés literario de la historia, su finalidad utilitaria y pragmática, y su fuerte sentido patriótico y propagandístico ${ }^{49}$.

No es accidental que desde mediados del siglo XV y a raíz de ese decisivo influjo renacentista, autores españoles como Alonso de Cartagena, Rodrigo Sánchez de Arévalo, Gonzalo García de Santa María o Alfonso Fernández de Palencia retornarán a escribir en latín, y a traducir obras clásicas, pero siempre, eso sí, sin perder de vista ese componente vernáculo de competencia y polémica frente a la supremacía italiana ${ }^{50}$. En el caso de Lucio Marineo Sículo, una de sus últimas y más importantes aportaciones historiográficas que, de algún modo, recapitulaba todas las anteriores fue: De rebus Hispaniae memorabilibus publicada en Alcalá en 1530, y en cuyo prólogo el mismo autor ya se designaba cronista de Carlos V 51 .

48 A este respecto, véase la apreciable proporción de crónicas medievales que aparecen en las bibliotecas femeninas de la ciudad de Valladolid entre 1529 y 1599 estudiadas con gran atención por CÁTEDRA, Pedro M. y ROJO, Anastasio: Bibliotecas y lecturas de mujeres, siglo XVI, Salamanca, (HILL), 2004, pp. 175 y 176. Algunos ejemplos más en el contexto de la Castilla medieval pueden verse en BECEIRO PITA, Isabel: «La relación de las mujeres castellanas con la cultura escrita (siglo XIII-inicios del XVI)», en Antonio Castillo Gómez (ed.), Libro y lectura en la Península Ibérica y América (siglos XIII a XVIII), Salamanca, Junta de Castilla y León, Consejería de Cultura y Turismo, 2003, pp. 42-45.

49 Ferguson, W. K.: Il Rinascimento nella critica storica, Bologna, 1969, p. 17. Seguimos las ideas aportadas por HINOJO ANDRÉs, Grégorio: «Nebrija y la historiografía renacentista: la fortuna» en Antonio de Nebrija: Edad Media y Renacimiento, op. cit., pp. 29-37.

so Cfr. FUETER, Eduardo: Historia de la bistoriografía... op. cit., pp. 155-157. Véase también WULFF, Fernando: Las esencias patrias..., op. cit., p. 20.

51 A la muerte de Isabel la Católica acompañó a Fernando en su viaje a Nápoles y una vez fallecido éste continuó desempeñando sus cargos en la corte con Carlos V. Vid. GIL FerNÁnDEZ, Luis: «La historiografía» en Historia de España fundada por Ramón Menéndez Pidal, XXI, p. 255.

Hispania, LXV/3, núm. 221 (2005) 877-938 
La presencia de esta obra en los inventarios madrileños fue relativamente discreta. Tan sólo la hallamos en once bibliotecas, tres de ellas: la del secretario Miguel Ruiz de Azagra, (1583) y las de los licenciados Gaspar de Vallejo (1623) y Juan Ochoa de Madariaga (1642). En 1623 un «Marino Sículo» aún se vendía en la tienda de librería de Antonio Rodríguez (1623) a tres reales el ejemplar. En verdad no acertamos con una razón convincente que explique esa supuesta «indiferencia» por la obra. En cualquier caso, la respuesta menos comprometida no puede ser otra que la falta de interés por parte del público lector, y, obviamente, no entra en nuestro cálculo pensar que fuera por estar escrita en latín. Entre esa selecta minoría de poseedores también estaban: Ana de Toledo, marquesa de Velada (1596), Juan de Acuña, marqués del Valle (1616) y Juan Hurtado de Mendoza, duque del Infantado (1624).

Menor divulgación disfrutó la obra del milanés Pedro Mártir: Décadas de Orbe Nouo, un tratado de corte etnográfico y naturalista que a pesar de hallarle únicamente en la biblioteca del anteriormente citado duque del Infantado; sabemos que, sin embargo, tuvo una trascendental magnitud historiográfica al ser el germen de la posterior y suculenta historia referida al Nuevo Mundo ${ }^{52}$.

De lo demás que ofrece este tiempo, añadir la figura de Lorenzo Valla como otro de los grandes humanistas que no negaron manifestar su admiración por la historia de España. Sin embargo, como en la mayoría de las citas sobre sus obras filológicas, la biografía que escribe sobre Fernando de Antequera, padre del monarca magnánimo: Historiarum Ferdinandi, Regis Aragoniae (Roma, 1520), aparece igualmente muy desdibujada en nuestros inventarios. Las parcas menciones al autor dificultan por entero la labor de distinguir con exactitud cuáles fueron sus obras más poseídas entre los madrileños. Con todo, cabe concluir que en general los temas históricos estrictamente italianos en ediciones originales, o traducidos al castellano interesaron, principalmente, a lo largo de la segunda mitad del siglo XVI, a la nobleza, alto funcionariado, juristas y clero, por ese orden, y en menor medida al resto de profesiones liberales, y de forma casi testimonial a oficios artísticos, mercaderes y artesanos. No así las historias nacionales como la Historia de Italia de Francesco Guichardini, y otras de ámbito universal como la de Giacomo Filippo de Bérgamo: Suma de todas las Crónicas del mundo, que gozaron de una sólida estabilidad a lo largo de todo el periodo, además de demostrar un dilatado abanico social de poseedores. De la traducción que hizo Narcís Viñoles a la obra de Bérgamo impresa en Valencia en 1510, encontramos un ejemplar entre los libros que Diego González Dulce pasó a su hija en concepto de dote (1600). En su versión latina: Suplementum Chronicarum (posiblemente la edición veneciana de 1513) se vendía a siete reales en la modesta librería de Antonio Rodríguez (1623).

52 Sobre Pedro Mártir y su concepto de «Novum Orbis», vid. Maravall, José Antonio: Antiguos y Modernos... op. cit., pp. $434-438$ y con relación a la obra: Esteve BARBA, Francisco: Historiografía indiana, Madrid, 1992, pp. 58-64. 
Sin contar las numerosas citas encontradas con el exclusivo nombre de su autor: Guichardini, en lo que respecta a su Historia de Italia, como adelantábamos, gozó de un amplio reconocimiento en la ciudad, especialmente en los ambientes más cultos y privilegiados. En 37 inventarios hallamos citas de este libro pertenecientes a nobles como Juan Enríquez de Guzmán (1591) con dos ejemplares, o Francisco Arias Dávila (1610) con tres; clérigos como Pedro Testai (1640), licenciados como Lorenzo Polo (1611), médicos como Juan Simón de Álava (1595) y servidores del rey como Fadrique Furió (1592), Gabriel de Zayas (1592), Pedro de Lira (1588), o Juan Portillo (1593). Llama la atención, sin embargo, las escasas referencias encontradas en los fondos de las tiendas de librería consultadas.

Asimismo, otra historia universal de origen italiano con una aceptable popularidad entre los lectores madrileños fue: Delle bistorie del mondo de Giovanni Tarcagnota; (Venecia, 1562) que formó parte de las lecturas de los capellanes reales, Oliverio Danis (1611) y Pedro Testai (1640). Una «Historia del Tarcanota» en cinco volúmenes, valorada en 44 reales, fue propiedad del famoso arbitrista Sancho de Moncada (1644) ${ }^{53}$. En edición italiana, la encontramos en otras selectas colecciones como las de los altos funcionarios Pedro de Lira (1588) y Jerónimo González de Heredia (1611), este último, a su vez, propietario de la Cronología del mondo de Francesco Sansovino, y de la mucho menos frecuente Historia Universale... de Gasparo Bugatti.

El autor que sí dejó sentirse con fuerza, al menos en los ambientes eruditos de la ciudad, fue Paulo Jovio, probablemente, junto a Guichardini, otro de los historiadores que mejor determinación tuvo a la hora de dictaminar los hechos de su tiempo. Según la interpretación de Fueter, Jovio tenía la sagacidad del periodista, reconociendo las necesidades de los nuevos tiempos antes de que las masas tuvieran conciencia de ello ${ }^{54}$.

Con la intención de enaltecer la figura militar de Carlos $\mathrm{V}$ escribe la afamada Historia general de todas las cosas succedidas en el mundo, traducida al castellano por Gaspar de Baeça y editada en Salamanca en 1562. Una obra que leían, entre otros madrileños, el médico de Felipe II Juan Simón de Álava e Ibarra (1595) y el licenciado del consejo de Su Mag. Gaspar de Vallejo Alderete (1623). La difusión de Jovio en la ciudad quedó suficientemente manifestada con nuevos escritos referidos a la figura del Gran Capitán: La vida y crónica de Gonzalo Hernández de Córdoua, que localizamos en varias colecciones de muy distintas consideración y tamaño, entre otras, la del boticario Diego de Burgos (1570), la del contador Alonso Ruiz de Valdivieso (1607) o la del capitán Jerónimo de Soto $(1630)^{55}$, pasando por las más distinguidas de don Jerónimo

53 A.H.P.M., protocolo 6639, (1644). Cfr. MARTZ, Linda: "La familia y hacienda del doctor Sancho de Moncada", en Anales Toledanos, XXIV, (1987), pp. 78.

54 FUETER, Eduardo: Historia de la bistoriografía... op. cit., p. 68.

ss Una aproximación a la biografía y vida intelectual de este militar puede verse en LASO BALLESTEROS, Ángel: «Tradición y necesidad. La cultura de los ingenieros militares en el Siglo de Oro: 
Manrique, obispo de Ávila e Inquisidor mayor del reino (1595), Juan Enríquez de Guzmán, mayordomo de sus altezas (1591) y Juan de Acuña, marqués del Valle (1616). Una «Historia del Iobio», así descrita, estaba incluida en los inventarios de Juan Portillo, contador de la Cruzada y en el de Mariana de Zúñiga, condesa de Nieva, (1628), que bien podría tratarse de alguna edición de la famosa Historiarum sui temporis. Concretamente, esta versión latina también formó parte de las lecturas de la marquesa de Velada Ana de Toledo (1596), del duque del Infantado Juan Hurtado de Mendoza (1624) y de Felipe de Aremberg, duque de Arischot (1640). De manera paralela circularon por Madrid no pocas ediciones en latín, italiano y castellano de los Comentarios de las cosas de los turcos que, en comparación con las anteriormente citadas apenas muestran desniveles socio-profesionales apreciables en su posesión, demostrando una sobrada continuidad hasta mediados del siglo XVII. Mencionemos finalmente los Elogios o vidas breues de los caualleros antiguos y modernos como parte del acopio de libros expuesto en la tienda de Antonio Rodríguez (1623).

Sobre la desbordante historiografía humanista de origen italiano que tanto interesó a los madrileños, tal vez cautivaron algo menos las historias particulares dedicadas a ciudades-estado como Florencia de autores como Leonardo Bruni o Poggio Bracciolini. Las referencias encontradas de la misma Historia florentina de Francesco Guichardini, una obra con la que se inicia -en palabras de Fueter- la moderna historiografía analítica y el razonamiento político de la historia, se pueden contar con los dedos de la mano. Algo similar ocurre con la Historia de Venecia de Bembo, pero quizás no tanto con la Rerum venetarum de Sabellico, o la Historia de Bolonia de Lambertini que hallamos en 17 bibliotecas, en su mayoría ( 71 por ciento) pertenecientes a la nobleza, alto clero, funcionariado, licenciados, abogados y oficios artísticos.

Independientemente de nuestros resultados, los hechos históricos evidencian que los vínculos diplomáticos, culturales y mercantiles con Italia, incluso los lazos entre particulares a través de viajes y estancias más o menos prolongadas favorecieron en España la influencia de este tipo de literatura. Diego Altamirano, fiscal en el supremo de Justicia (1642) poseía un ejemplar del Discorso dell' origine e antichita di Palermo de Mariano Valguarnera, editado en Palermo en 1614. A principios del siglo XVII el jurista Camilo de Negrón (1607) recogía en su seleccionada colección una República di Genova de Uberto Foglietta (Roma. 1559) y un «Origene de la cita de Milan, en italiano» que identificamos con la escrita por Bernardino Corio. Los secretarios reales Gabriel de Zayas (1592) y Jerónimo González de Heredia (1611) leyeron la Historia de Sicilia de Tommaso Fazello en su edición veneciana de 1573, y sobre ese mismo género tenemos noticia de un manuscrito en la biblioteca de Juana de Mújica y Butrón (1617) intitulado «Relación del Reyno de Sicilia».

la biblioteca y la galería del capitán don Jerónimo de Soto», en Cuadernos de Historia Moderna, 12, UCM (1991), pp. 83-109. 
Pero quizás el verdadero interés literario por este tipo de historias tuvo su principal reflejo en las ciudades de Nápoles y Roma, bien es cierto que en la mayoría de las ocasiones citadas de forma muy parva y sin apenas alusiones al autor. Las numerosas «Historia de Nápoles» que se relacionan, acaso aludieran a la de Pandolfo Colenucio que contabilizamos de manera más nutrida durante el último tercio del siglo XVI y tres primeras décadas del XVII. Similar cronología la ofrece el texto de Giovanni Pontano: De bello neapolitano, (Nápoles, 1509) que, a diferencia de la anterior, sólo muestra una menor pluralidad desde el punto de vista socio-profesional. La «Historia del reyno de Nápoles», así descrita, se vendía a seis reales en la tienda regentada por la viuda del librero Pedro de la Torre (1607). A ese mismo precio, pero en formato folio, se exponía en los estantes de las librerías de Juan Hasrey (1615) e incluso, años más tarde, en 1624, en la de Juan del Casar.

Con relación a la ciudad de Roma, la Descriptio urbis Romae de Leon Battista Alberti muestra una tendencia mucho más selectiva desde el punto de vista de la posesión, con seguridad por tratarse de una valiosa edición repleta de primorosas ilustraciones, y, por tanto, no asequible para cualquier bolsillo. Una difusión algo mas difuminada se aprecia en los títulos denominados «Maravillas de Roma», que identificamos, entre otras posibles alternativas, con la traducción de Las cosas maravillosas de la santa ciudad de Roma (Roma, 1589). Son 65 inventarios los que registran este título, pero en su conjunto apenas puede establecerse diferenciaciones en cuanto a evolución cronológica y divulgación. Por su parte, el famoso platero Juan de Arfe (1603) tenía una edición Dell'anticbitá della Citta di Roma de Bernardo Gamucci (Venecia, 1565), y en la biblioteca del licenciado Juan Ochoa de Madariaga (1642) aparece un libro descrito como «De urbis Roma de Fulvius» que, evidentemente, alude a la obra de Andrea Fulvio: De urbis antiquitatibus Roma, (1545). En el inventario de los libros de Fadrique Furió (1592) se relaciona una «Fundación de Roma, en italiano» que tal vez, de manera distorsionada, indicara igualmente la obra de Fulvio.

Frente a las grandes historias oficiales volcadas a atender los intereses universales de la corona - por otro lado, llevadas a tratar de manera unitaria los grandes hechos de los españoles y demás excepcionales temas de estado- se pusieron de moda desde mediados del siglo XVI y de manera más notable durante todo el XVII las historias locales, quizás como remèdo de las primeras grandes historias de las ciudades, símbolo de la Italia renacentista, vistas anteriormente.

Estas historias locales se orientaron a describir — desde unos planteamientos autónomos y únicos - las peculiaridades geográfico-históricas de determinados territorios, municipios y ciudades. A través de un exhaustivo tratamiento descriptivo y cronológico se reconocían todas las más singulares laudationes, glorias y excelencias de los lugares en cuestión, desde sus más primitivos vestigios hasta los que aún se estaban viviendo. Afirma Kagan que el género corográfico no sólo representó una expresión cultural de los pueblos, sino un discurso que permitió a sus naturales desarrollar a través del tiempo su propio 
sentido de identidad y de "patria»" ${ }^{56}$. Pero el género corográfico - como paralelamente también han interpretado Ofelia Rey o Pedro M. Cátedra- sirvió para reivindicar a una ciudad ante sí misma y con respecto a las demás, para legitimar y consolidar el poder de sus oligarquías como garantes de su continuidad genealógica, en definitiva, para apuntalar la autonomía de las ciudades frente a las posibles amenazas a sus privilegios por parte de la monarquía ${ }^{57}$. Por su parte, Alfredo Alvar cuestiona la generalización de esta afirmación, poniendo en duda que tales historias se usaran como elementos de disidencia antimonárquica al objeto de fortalecer a las ciudades en contra del rey ${ }^{58}$.

En cualquier caso, a tenor del concreto modelo de posesión que vemos configurarse en Madrid, permite imaginarse de qué manera estas historias particulares debieron ser para un sustancial número de lectores la expresión literaria más cercana a sus lugares de origen, la historia de las pequeñas patrias naturales de cada uno.

Del mismo modo, es posible intuir cómo de su lectura se podían llegar a revelar diferentes situaciones personales, no sólo relacionadas con el elemental conocimiento, sino con la cercana evocación a una determinada descripción, incluso sobre la puntual percepción de una realidad vivida o anhelada. En ese sentido, tal vez, sería factible explicar la posesión de ciertas obras tan diferentes y de ámbitos geográficos tan alejados como las halladas en el estudio del secretario Miguel Ruiz Azagra (1583): entre otras, una Historia da antiguidade da cidade de Euora de André de Resende (Euora, 1576) y las Grandezas y cosas memorables de la ciudad de Tarragona de Luis Pons de Icart (Lérida, 1572). De la misma manera cabría especular, por qué no, en la permeabilidad receptiva de determinadas figuras literarias, como pudo ser el caso de la popular Historia de Sagunto de Lorenzo Zamora (Alcalá, 1589) conservada en la biblioteca del poeta Alonso de Ercilla (1594) provocando algunas posibles imágenes de inspiración en el autor de la Araucana.

¿Existieron algunos intereses solariegos que condujeran a la marquesa de Cenete, doña María de Mendoza y Fonseca (1580) a leer la Historia de Toledo de Pedro Alcocer, y la Crónica de Valencia de Martín de Viciana? ¿Qué motivos llevaron al guantero Francisco Moreno (1627) a adquirir la no demasiado frecuente: Fundación, excelencias, grandezas y cosas memorables de la antiquisima ciudad de Huesca (Huesca, 1619)? ¿Tal vez fue originario de allí?

56 KAGAN, Richard L.: «La corografía en la Castilla Moderna. Género, historia, nación» en Stvdia Historica. Historia Moderna, vol. XIII (1995), p. 48.

57 REY CASTELAO; Ofelia: Libros y lectura en Galicia. Siglos XVI-XIX, Santiago de Compostela, 2003, pp. 601 y 602; CÁTEDRA, Pedro M.: «La biblioteca y los escritos deseados (España, c. 1605)», en El Libro Antiguo Español, V, "El escrito en el Siglo de Oro: prácticas y representaciones", dirigido por Pedro M. Cátedra; Agustín Redondo y María Luisa López-Vidriero, Salamanca, 1999, pp. 60 y ss.

58 Alvar EzQuerra, Alfredo: «Corografía y exaltación de lo local en la época de Calderón», en José Alcalá-Zamora y Ernest Belenguer: Calderón de la Barca y la España del Barroco, Madrid, 2002, pp. 445-459. 
Sintetizando los datos sobre el espacio que esta concreta producción historiográfica ocupó en nuestras bibliotecas conviene advertir que la difusión en términos absolutos fue mucho más ocasional y diseminada entre los inventarios de la segunda mitad del XVI que en los de la siguiente centuria. Eso sí, obviamente, habrá que entender que este mayor interés también se vio condicionado por la circunstancia de coincidir con un número superior de obras en circulación. Por ejemplo, entre los pocos libros del boticario Diego de Cortavila (1615) se relacionaron la Descripción del reyno de Galizia escrita por el licenciado Juan de Molina, y una «Descripción de Cartagena» que acaso hiciera alusión al Discurso de la ciudad de Cartagena de Francisco Cascales, (Valencia, 1598). El caballero de Santiago Gaspar de Vallejo y Alderete (1623), y el oficial del consejo de Estado Esteban Arias (1626) tenían el Teatro de las grandezas de la villa de Madrid de Gil González Dávila, editado en Madrid por Tomás de Junti en 1623, más otro de la Historia de Sevilla de Alonso Morgado (Sevilla, 1587), y unas Cosas notables de Granada de Luis de la Cueva (Sevilla, 1603). El también noble Juan de Castañeda (1628) pudo conformase con una sola «Descripción de Numancia, de mano», mientras que el clérigo Francisco Manuel de Zamora (1650) tuvo posibilidad de leer la muy documentada Relación de las inscripciones $y$ antigüedad de la villa de Utrera de Rodrigo Caro. Completamos este repaso con la reconocida Historia de las antigüedades de Salamanca de González Dávila propiedad del secretario real Juan Fernández de Madrigal (1632).

El análisis cuantitativo de los inventarios establece que es durante el periodo 1601-1650 cuando encontramos el número más abultado de bibliotecas con obras corográficas. Por su abundancia y diversidad son las bibliotecas de los grupos privilegiados, principalmente nobles, las que sobresalen del resto. Sin embargo, aunque sea inexacto hablar de baja posesión entre oficios artísticos, mercaderes o artesanos, hemos comprobado que para algunos de ellos este tipo de historias eran las únicas que parecían poseer ${ }^{59}$.

El marqués del Valle Juan de Acuña (1616) dejó en el momento de su muerte hasta once historias de ciudades entre las que se encontraban: las Grandezas de la muy insigne ciudad y iglesia de León de fray Atanasio de Lobera (Valladolid, 1596), la Historia de Sevilla de Morgado y la Antigüedad y excelencias de Granada de Francisco Bermúdez de Pedraza (Madrid, 1608). El también noble, Juan Hurtado de Mendoza y de la Vega (1624) acumuló hasta trece corografías tales como la Historia de Toledo con dos ejemplares, las «Antigüedades de Medina del Campo» y una poco conocida "Historia del Peñón de Vélez» que bien pudiera hacer referencia a la Historia escrita por Alfonso de Ulloa ${ }^{60}$. Pero, sin duda, la colección madrileña que mejor refleja este género corográfico es la de

59 De los cuatro libros que aparecen en el inventario de bienes del maestro de origen italiano Juan Turín (1614), solamente aparece una «Historia de Granada» que bien pudiera referirse a la obra de Luis de la Cueva: De las cosas notables de Granada... (Sevilla, 1603).

60 La Historia dell'impresa di Trípoli di Barberia, della presa del Pegnon di Velez della Gomera in Africa... (s.l.: s.i., s.a.).

Hispania, LXV/3, núm. 221 (2005) 877-938 
Juan Alfonso Enríquez de Cabrera (1647). En ella junto a las historias de ciudades italianas (algunas tan poco convencionales como las de Parma, Verona, Catania, Cremona, Pavía, Mantua o Calabria), el almirante de Castilla era propietario de una "Historia de Toledo y Zaragoza en un solo cuerpo», más otros dos ejemplares de la Historia de las grandezas de la ciudad de Ávila de fray Luis Ariz (Alcalá, 1607), la Historia y anales de la ciudad y obispado de Plasencia de Alonso Fernández (Madrid, 1627), la Historia de la ciudad de Cuenica de Juan Pablo Mártir Rizo, y el Teatro de las grandezas de Madrid de González Dávila. La lista continuaba con dos ejemplares, dedicados a la historia de Valencia: uno, de las Décadas de la Historia de la ciudad y reyno de Valencia del cronista Gaspar Juan Escolano, en edición de Valencia de 1611, y otro de la Crónica del Reyno de Valencia de Martín de Viciana, además de la Historia de Toledo de Alcocer, los Discursos históricos de la ciudad de Murcia de Francisco Cascales (Murcia, 1621), la Historia de Sagunto de Lorenzo Zamora, una «Antigüedad de Ecija» probablemente de la que fue autor Martín de Roa (Sevilla, 1629), y, para terminar, las Grandezas y antigüedades de la isla y ciudad de Cádiz de Juan Bautista Suáreż de Salazar (Cádiz, 1610).

Los fondos de seis negocios de librería madrileños, igualmente, subrayan esta aceptable circulación durante el Seiscientos: en la tienda de Antonio Rodríguez (1623) se vendían dos «Grandezas de Cádiz» y nueve copias de una «Historia Saguntina» tal vez la citada Historia de Sagunto de Lorenzo Zamora. Por un real se conseguía esa misma obra en la tienda del librero Jusepe de Vidarte ${ }^{61}$. Y junto a las gradas de San Felipe, a la entrada de la calle Mayor, en la covachuela del librero Miguel Martínez (1629) ${ }^{62}$ estaban expuestas al público treinta «Historia de Murcia» al precio de diez reales cada una. Tan sólo dos ejemplares de la «Historia de Toledo», más uno de la Antigüedad y excelencias de Granada de Bermúdez de Pedraza se detallan en los fondos del librero Juan del Casar (1624). Hasta nueve «Antigüedades de Toledo» localizamos entre los del mercader de libros Cornelio Martín (1620). Otras dos copias de las «Grandezas de Ávila» se registraron en el inventario de la librería de Juan Hasrey (1615).

Entrando en el examen de otras series historiográficas que alcanzan a este periodo, de nuevo se sigue advirtiendo la amplia iniciativa demostrada por la producción editorial española, y en concreto por la madrileña, favorecida por el impulso humanístico iniciado en Italia.

Desde la disposición casi mesiánica del gran momento constructor de identidades colectivas que supuso el naciente estado moderno, los Reyes Católicos simbolizaron mejor que nadie esa idea de Estado que empezaba a reforzar las señas de identidad dinástica de la propia monarquía, impulsando una historio-

${ }_{61}$ A.H.P.M. (escritura de capital, protocolo 2447. 1611-IV-15); (inventario post-mortem, protocolo 5065. 1624-IX-1).

.62 Esta librería fue estudiada hace años por: Dadson, Trevor J.: «La librería de Miguel Martínez (1629), librero y editor del primer tercio del siglo XVII», en «Les livres des espagnol á l'époque moderne», Bulletin Hispanique, 99 (1997), pp. 41-71. 
grafía renacentista de prestigio con claras determinaciones patrióticas. Una forma de historiar que necesitaba crear nuevas representaciones del pasado para explicar y ensalzar - también de cara al exterior- la posición alcanzada, todo ello sin relegar la deseable finalidad moral de la historia y su interés literario. Valga el ejemplo de la Cronica de los señores Reyes Católicos don Fernando y doña Isabel (Valladolid, 1565) de Hernando del Pulgar (concluida por Alonso de Santa Cruz) que encontramos en no demasiados, pero sí selectos inventarios que vienen a evidenciar ese interés lector por parte de determinados personajes cultos y avisados como fueron Luisa de Sanleger, marquesa de La Adrada (1598), Francisco de Oseguera, alguacil de la Inquisición (1599), el conde de Osorno García Fernández Manrique (1587), Mariana Correa (1588) o Juan de Castañeda y Ronquillo, caballero de Santiago (1628), entre otros.

Uno de los primeros autores españoles que mejor supo adaptarse a los fundamentos historiográficos de cuño humanista fue Nebrija, especialmente a través de las concepciones metodológicas propuestas por la escuela de Bruni. Antonio de Nebrija, como cronista de la reina Isabel (1509) y tomando como base la crónica de Pulgar, redactó su Rerum a Fernando et Elisabe... gestarum Decades duae (Granada, 1545), una obra que hallamos esporádicamente citada hasta bien entrado el siglo XVII, de nuevo, principalmente, en bibliotecas de titularidad nobiliaria como las de Juan Alfonso Enríqueż de Cabrera (1647), Juana González de Armunia (1634) o Pedro de Granada (1643). El médico real Juan Simón de Álava (1595) era propietario de una «Chronica de los muy altos y esclarecidos reyes Catholicos compuesta por el maestro Nebrixa» valorada en seis reales. Con similar descripción se anota en la copiosa biblioteca del abogado Ortiz de Truxeque (1598), y en el inventario de la tienda de librería de Jusepe Vidarte (1624), valorada en 12 reales.

Es incuestionable que la unión de Castilla y Aragón, la conquista de Granada, el descubrimiento de América o la más tardía anexión de Navarra, fueron acontecimientos que incrementaron el prestigio de los nuevos monarcas y fomentaron, desde el papel hegemónico de Castilla, la tarea de «inventar» y consolidar la historia de España ${ }^{63}$. En esa línea de continuidad surgen una serie de historias generales de España escritas con la intención de cubrir acaso la falta de una producción similar a la que se estaba haciendo en el resto de Europa. Una realidad que el mismo Ambrosio de Morales en el prólogo a su Crónica General de España llega a denunciar las «muchas veces [que los extranjeros) nos dan en el rostro con que nunca hemos sido los españoles para hazer una historia de nuestras

63 En toda Europa se darían procesos comparables. Fernando Wulff tomando como base argumental la obra de F. Guizot: Historia de la civilización en Europa (desde la caída del Imperio romano basta la Revolución Francesa), Madrid, 1972, hace notar cómo en los diferentes espacios europeos también se constituyeron entidades políticas y concentraciones de poder sin precedentes desde muchos siglos antes, entidades que tendrán una continuidad también única, que pondrán en funcionamiento aparatos estatales y formas organizativas adaptadas a estas exigencias, y que se hallarán con frecuencia en guerra y conflicto en el exterior, y en la necesidad de ganar y mantener su hegemonía frente a otros poderes en el interior. Vid. WULFF, Fernando: Las enseñanzas patrias..., op. cit., p. 16.

Hispania, LXV/3, núm. 221 (2005) 877-938 
cosas, ni dar una buena relación de nuestras antigüedades» ${ }^{64}$. En definitiva, unos relatos que son la clara manifestación de un nuevo momento de creación historiográfica y de afianzamiento de la identidad nacional, y que dado su gran desarrollo, en lo que toca a nuestras bibliotecas madrileñas apenas se advierten contornos en cuanto a tramos de divulgación, poseedores y asuntos.

Las muchas ofertas editoriales que se hicieron sobre estas Crónicas generales facilitaron la iniciativa política de avalar unos modelos historiográficos que se proyectaron sobre el interés generalizado de la sociedad lectora madrileña: la Crónica de España abreviada de Diego de Valera (Sevilla, 1517), la Crónica general de España de Florián de Ocampo (Zamora, 1544) y la que continuó Ambrosio de Morales (Alcalá, 1574), el Valerio de las historias escolásticas y de los hechos de España de Diego Rodríguez de Almella (Toledo, 1520), junto al Libro de grandezas y cosas memorables de España (Sevilla, 1548) del célebre cosmógrafo Pedro de Medina, disfrutaron de una amplísima resonancia. También fueron celebradas en la ciudad, aunque en menor grado: el Chronici rerum memorabilium Hispaniae de Juan Vaseo (Salamanca, 1552) que sólo hemos encontrado en inventarios de sectores privilegiados y, excepcionalmente, en la biblioteca del alférez de la guarda alemana Adán Valderfinger (1585), poseedor además de un «Catálogo biográfico de los reyes de España escrito en latín» de posible identificación con el de Francisco Tarafa: De origine ac rebus gestis regum Hispaniae (Amberes, 1553).

Valores sobresalientes de aquellos tiempos de invención y consolidación de la identidad de los modelos globales hispanos se demostraron en el Compendio Historial de Esteban de Garibay y Zamalloa (Amberes, 1571), en las Excelencias de la Monarchia y reyno de España de Gregorio López Madera (Valladolid, 1597), y en la Corónica general de toda España compuesta por Pedro Antonio Beuter (Valencia, 1546). Como consecuencia de la prolongación de ese interés historiográfico por consolidar y exponer esa realidad nacional, igualmente, merece una atención especial la Historiae de rebus Hispaniae de Juan de Mariana (Toledo, 1592 y su posterior traducción al castellano en la misma ciudad en 1601). Con ella no puede decirse que los contenidos cambiaran de manera radical, pero sí se percibe una conciencia histórica y política que se manifiesta si cabe con más grandeza y satisfacción. Mariana da a conocer el memorable pasado de España no ya desde la exclusiva filiación con un determinado monarca, sino conjuntamente desde la propia identidad que ahora fluía del pueblo mismo ${ }^{65}$.

64 Cit. por Alvar EzQuerRA, Alfredo: «Sobre historiografía castellana en tiempos de Felipe II (Unas biografías comparadas: Sepúlveda, Morales y Garibay)», en Torre de los Lujanes, n 32, (1996), p. 99.

6s Mariana, al avenirse al sentido moralizador y apologético de la historia dando por veraces algunos hechos manifiestamente inciertos, provocó una curiosa disputa historiográfica entre las Advertencias a la Historia... (1611) de Pedro Mantuano, y la «defensa» de Tomás Tamayo de Vargas en la Historia... de Mariana defendida... (1616), ambas, suficientemente bien representadas entre el público lector madrileño. Al menos cincuenta "Aduertencias de Mariana", así descritas, tasadas en 150 reales, se relacionaron en el inventario del mercader de libros Cornelio Martín (1620). Un 
Como decíamos, las muchas referencias encontradas de estas obras entre el amplio abanico socio-profesional madrileño no permiten hablar de diferencias apreciables en cuanto a su posesión, ni tampoco la distinción de movimientos reseñables respecto a su continuidad en el tiempo. Entre los autores que aparecen con mayor regularidad (aproximadamente en un 43 por ciento) tenemos al quinteto formado por Juan de Mariana, Ambrosio de Morales, Florián de Ocampo, Esteban de Garibay y Diego Valera, por ese orden.

Sin contar los largos éxitos editoriales de Garibay y, sobre todo, Mariana, resulta sorprendente que algunos de los otros (en concreto: Morales, Ocampo o Valera) aún a mediados del siglo XVII tuvieran una más que respetable y fiel clientela. En 1615 el mercader de libros Juan Hasrey vendía la Historia de Mariana, encuadernada en formato folio, a 30 reales, y sin encuadernar a ocho. En la tasación de los libros del capitán Jerónimo de Soto (1630), la obra de Mariana se estimó en 26 reales, y la Historia de España de Ocampo en dos ducados. Leocadia Enríquez (1644) pudo leer conjuntamente, entre otros historiadores, a Garibay, Mariana, Morales y Ocampo. La España abreviada de Valera fue objeto de lectura de clérigos como Fernando de León (1599) y Francisco Manuel de Zamora (1650), o de nobles como María de Fonseca (1580) y Juan Fernández de Velasco (1608). En el mismo inventario post-mortem de Pedro de Granada $(1643)$ se anotó el siguiente registro: «Una Chronica de España de mossen Valera, antigua». El Compendio historial de Garibay, en tres cuerpos, propiedad del comendador Juan Enríquez de Guzmán (1591) se valoró en la importante cantidad de doce ducados, y, a su vez, las «Cuatro partes de los reyes de España de Garibay» alcanzaron los 48 reales en la tasación de los libros del boticario Diego Carrillo (1641). En la almoneda de los bienes del secretario del rey don Juan Hurtado de Mendoza (1616) se remató en Simón de Badillo la «Crónica de Garibay» en 50 reales. Un "Compendio de Zamalloa», en tres cuerpos encuadernados en cuero azul, se guardaba en la biblioteca de Juan de Ovando (1575), y hasta dos «Historias de Garibay» tenía el licenciado Juan Ochoa de Madariaga (1642). El único libro que aparece entre los bienes de la viuda Leonor Quiñones (1593) fue un «Zamayoa».

Junto a todos éstos, el otro gran historiador que se consolida como referencia imprescindible de la historiografía nacional fue Jerónimo Zurita. En palabras de Fueter se trata del gran continuador del método historiográfico italiano del siglo XV ${ }^{66}$. Sus Anales de la Corona de Aragón (Zaragoza, 1562) para Sánchez Alonso constituyeron «la expresión de todo lo que en el siglo XVI podría investigarse sobre un reino medieval, comprendiendo, junto a la historia políti-

ejemplar editado en Madrid por la Imprenta Real en 1613 se encontraba entre los libros del licenciado del consejo de Su Mag. Gaspar de Vallejo (1623).

66 FUETER, Eduardo: Historia de la historiografía... op. cit., pp. 259-260.

Hispania, LXV/3, núm. 221 (2005) 877-938 
ca, noticias de los ricos-hombres, la institución del Justicia, heráldica, concilios, fundaciones de monasterios, etc. ${ }^{67}$.

Tenemos noticia de esta obra en el 28 por ciento de las bibliotecas nobiliarias madrileñas, en el 22 de las del funcionariado y en el 14 por ciento de las del clero. En el otro extremo de los grupos lectores (mercaderes y artesanos, por ejemplo) también se distinguen significativos porcentajes ${ }^{68}$. En cuanto a su continuidad se aprecia una tendencia al alza que situamos en un siete por ciento a favor del periodo 1601-1650, respecto del anterior.

Ante la amplia nómina de poseedores de esta notable obra sólo optamos por apuntar algunas noticias concretas, como los «cuatro juegos de a siete volúmenes cada uno» de los Anales de Zurita, en folio, valorados en 121 reales unidad, que tenía el librero Juan Hasrey (1615); o los 20 reales que se pagaron por los «seis cuerpos de los Anales de Zurita» en la almoneda de los libros del conde de Osorno Fernández Manrique (1587). Hasta ocho ducados abonó el licenciado Yáñez por unos «Anales de Zurita» que pertenecieron a la biblioteca del marqués de Campotéjar (1643).

La otra gran obra de Zurita: Indices rerum ab Aragoniae Regibus gestarum (Zaragoza, 1578) gozó de mucha menor proyección, por ejemplo, de forma puntual la localizamos junto a los Anales y la obra de Jerónimo de Blancas: Aragonensium rerum commentarii (Zaragoza, 1588) en la biblioteca del consejero del rey Agustín Álvarez de Toledo (1601).

Pero los historiadores de este periodo no sólo compitieron en cantar las glorias nacionales, también marcaron diferencias a la hora de enaltecer los valores y sucesos protagonizados por los monarcas de su tiempo. Carlos V y Felipe II ocuparon lugar preferente en las estrategias editoriales del momento y, en consecuencia, sus historias se instalaron generosamente en los contornos lectores de la ciudad. No tanto se puede decir de la presencia de textos dedicados a Felipe III, y apenas poco más en los que hablaban de la figura de Felipe IV, siempre teniendo en cuenta, eso sí, que nuestra encuesta sólo llega hasta mediados del siglo XVII.

Pedro de Mejía fue invitado por Carlos V en 1548 a historiar su reinado nombrándole cronista real. Para tal misión, y con «ciega admiración» —en palabras de Sánchez Alonso- inició una Historia de Carlos Quinto (inconclusa) ${ }^{69}$, cuyo relevo historiográfico, medio siglo después, asumió el cronista oficial de Felipe III, desde 1600, Prudencio de Sandoval en su Historia de la vida y hechos del emperador Carlos V (Valladolid, 1604 a 1606), considerada por García

67 SÁNCHEZ AlONSO, Benito: Historia de la historiografía..., op. cit., vol. II, pp. 33-34.

68 Cfr. PRIETO BERNABÉ, José Manuel: Lectura y lectores... op. cit., vol. I. p. 313.

69 El hecho de que cronistas como Mejía y Santa Cruz, como consecuencia de su muerte, dejaran inacabadas sus crónicas y, por tanto, sin publicar, no fue impedimento para que los manuscritos circularan con relativa profusión. Vid. CUART MONER, Baltasar: «La historiografía áulica...», op. cit., p. 41. 
Cárcel como «la mejor historia de Carlos $\mathrm{V} »^{70}$. No obstante, las grandes dotes de historiador de Pedro de Mejía quedaron plasmadas en su documentada y extensa Historia Imperial y Cesárea (Amberes, 1561) al evocar con gran maestría discursiva las glorias pasadas que se sucedieron desde Julio César hasta Carlos V. La obra saboreó una sobresaliente acogida en Madrid (aunque sin llegar a la registrada con su afamada Silva de Varia Lección), un hecho que queda avalado por las sucesivas ediciones de que fue objeto. De los 59 ejemplares identificados en nuestras bibliotecas, el 35 por ciento corresponden a recuentos posteriores a 1600, y con relación al general reparto socio-profesional de sus poseedores no es aventurado calificarlo de relativamente equilibrado: el 21 por ciento tiene como titulares a nobles; el 22 por ciento a funcionarios en general, el 9 a clérigos y el 13 a profesionales liberales, en su mayoría, relacionados con funciones jurídicas. Entre los mercaderes y artesanos suman el 19 por ciento, mientras que el resto se reparte entre titulares sueltos, más algunos sin perfil sociológico concreto.

Tenemos datos sobre otras historias sensibles a la propaganda de la persona y política del emperador, o alusivas a alguno de sus ascendientes, por ejemplo: el Comentario... de la guerra de Alemania becha de Carlos $V$ de Luis de Ávila y Zúñiga. Una obra bien documentada, presente en dieciséis bibliotecas de la nobleza y alto funcionariado madrileño, en nueve del clero en general, en trece de abogados, médicos y licenciados, y en doce de oficios artísticos, mercaderes y artesanos, y en diecinueve más de titularidad varia y sin profesión declarada. Cronológicamente, el 63 por ciento de los inventarios con su mención expresa fueron fechados entre 1550 y 1600.

$\mathrm{Al}$ inventariar los bienes de personajes principales como don Juan Enríquez de Guzmán (1591), la marquesa de Velada doña Ana de Toledo (1596), Sancho Ochoa de Castro, gobernador y capitán general de Puerto Rico (1611), el marqués don Juan de Acuña (1616) o Pedro Illán de Liébana (1594) hallamos la traducción que realiza Pedro de Aguilón de la Historia del Duque Carlos de Borgoña de Felipe de Comines, (Pamplona, 1586). Por su parte, la crónica satítico-bufonesca de don Francesillo de Zúñiga, la encontramos, excepcionalmente, en versión manuscrita, entre los libros de Isabel Maldonado (1576) y en los del noble Pedro de Granada (1643). Además, la biografía y los hechos militares de don Juan de Austria fueron recogidos en el libro del presbítero madrileño, de origen flamenco, Lorenzo van der Hammen: Don Juan de Austria: bistoria, editado en Madrid por Luis Sánchez en 1627 y que, entre otros, poseía Ana Martínez Cabrera (1637). Sin embargo, la "Historia de don Juan de Austria» que vendía el librero Vidarte (1624) al precio de tres reales, es probable que fuera la escrita por Jerónimo de Costiol: Crónica del muy alto y poderoso príncipe don Juan de Austria (Barcelona, 1572).

70 GARCÍA CÁRCEL, Ricardo: «Carlos V y sus historiadores», en «V Centenario del nacimiento de Carlos V». XIV Coloquio de Historia canario-americana, 2000, Las Palmas de Gran Canaria, 2003, p. 103.

Hispania, LXV/3, núm. 221 (2005) 877-938 
Ya en tiempos de Felipe III y Felipe IV la citada Historia de la vida y hechos del emperador Carlos $V$ de fray Prudencio de Sandoval se revela como una de las mejores aportaciones. La vemos anotada en 46 inventarios particulares de muy distinta consideración socio-profesional, incluso su desahogado mercado se refleja en algunos fondos de tiendas de librería: hasta 19 juegos de la obra de Sandoval encuadernados «en pergamino con botoncillos», se podían adquirir en la librería del citado Jusepe Vidarte a 50 reales el ejemplar.

Como corolario del importante eco lector que alcanzó la figura del emperador, se editó la biografía laudatoria escrita por el nieto del citado Luis de Avila, Juan Antonio de Vera: Epitome de la vida y bechos del invicto Emperador Carlos V, (Madrid, 1622), que hallamos descrita en 58 bibliotecas de titularidad y naturaleza muy variada: desde las colecciones sin grandes pretensiones intelectuales del escribano Domingo de la Torre (1625) o la viuda María de Trueba (1629), pasando por las modestas del capitán Jerónimo de Soto (1630), del ciudadano Francisco Maldonado Patiño (1644) o la del contador del consejo de Castilla Juan Cortés de la Cruz (1651), hasta las más aventajadas de Mariana de Zúñiga (1628) y Pedro de Granada (1643).

De contenido más literario que histórico la figura de Carlos $\mathrm{V}$ aún inspiró varias loas. Una de las más aplaudidas en Madrid fue el Carlo Famoso de Luis Zapata, editado en Valencia en 1566, y registrado entre otras bibliotecas en las de Juan de Ovando (1575) y Mariana Correa (1588). En términos parecidos, consagrado a enaltecer la figura del emperador, Jerónimo Sempere publicó la Corolea (Valencia, 1560) que, al igual que la anterior, mostró algunos signos de distinción social entre los madrileños. La leyeron, entre otros, el arbitrista Sancho de Moncada ${ }^{71}$ y el marqués de Santa Cruz don Álvaro de Bazán (1645). En la misma tasación de los libros de Francisco Ruiz de Ondárroa, ayuda de guardajoyas del rey (1629) llegó a valorarse en 20 reales. Otro ejemplar de la obra de Sempere, junto a una «Vida de Carlos Quinto, en italiano» que posiblemente hiciera mención a la obra de Ludovico Dolce, fue objeto de lectura por parte de notables personajes como Pedro Juan de Lastanosa (1576) ${ }^{72}$ y Jerónimo González de Heredia, secretario real (1611). Una "Carolea de Carlos quinto» —así citada - se tasó en 22 reales en la librería de Cristóbal López (1606).

Valorar mínimamente los actos de lectura que llevaron como protagonista la personalidad histórica de Felipe II y su época obligaría a revisar otra amplia nómina de autores y obras con sus respectivos distribuidores y poseedores. $\mathrm{Al}$ menos, por lo analizado en nuestra documentación, la producción literaria sobre dicho personaje y reinado no rompe con la línea de continuidad institucional iniciada en el de su padre. Incluso, como ha señalado Bouza, después del eclipse historiográfico transitorio coincidente con los primeros años del reinado

71 A.H.P.M., protocolo 6639 (1644).

72 A.H.P.M., protocolo 939 (1576). Cfr. Alvar EzQuerra, Alfredo y Bouza Álvarez, Fernando J.: «La librería de don Pedro Juan de Lastanosa en Madrid (1576)», en Arcbivo de Filología Aragonesa, XXXII-XXXIII, p. 140. 
de Felipe III, la memoria del Rey Católico recobra su esplendor durante la segunda década del siglo XVII ${ }^{73}$ con rendidas biografías de glorificación como la escrita por Luis Cabrera de Córdoba: Filipe Segundo, Rey de España (Madrid, $1619)^{74}$, o historias con miras algo más universales centradas, sobre todo, en torno a los hechos generales del reinado más que en los de la propia biografía, caso de la Historia general de mundo... del tiempo del rey Don Felipe (Madrid, 1601) del cronista Antonio de Herrera y Tordesillas 75 .

Menor reclamo demostró la historia del madrileño Lorenzo Van der Hammen y León, editada en Madrid por la viuda de Alonso Martín en 1625 y titulada: Don Felipe el Prudente. Segundo deste nombre, que tan sólo hallamos en once colecciones con el siguiente reparto: cuatro de nobles, dos de funcionarios, dos de profesiones liberales, una de oficios artísticos, más dos sin profesión declarada. Llama la atención que el único impreso que aparece en el más que aceptable inventario de bienes del secretario de la Inquisición de Sevilla Juan de Fontao (1631) fuera una «Historia de Felipe II». No obstante, en términos concluyentes podemos afirmar que, tanto por su naturaleza como por su consolidación social, estamos ante un conjunto de obras que penetran con relativa decisión y persistencia hasta bien pasada la segunda mitad del XVII.

Con una breve mención situamos aquí los escritos dedicados a las genealogías e historia de ilustres pasados nobiliarios. En primer lugar, es necesario aludir a la recurrente cualidad de una historiografía claramente justificativa del fundamento estamental, muy acorde en estructura y discurso a los valores mostrados en el caso de la historia de los personajes de la realeza y en la que, de forma semejante, concentra sus lectores en un parecido círculo de recepción, aunque curiosamente no protagonizado de manera exclusiva por su principal y teórico destinatario, la nobleza.

En ese sentido hemos creído oportuno valorar la diversidad de al menos tres obras de las más poseídas de este género: Nobleza de Andaluzía de Gonzalo Argote de Molina (Sevilla, 1588); Nobiliario General de Reyes y títulos de España de Alonso López de Haro (Madrid, 1622) y Discurso de la Nobleza de España de Bernabé Moreno de Vargas (Madrid, 1622). De los 68 ejemplares identificados, el reparto por grupos socio-profesionales mantiene el siguiente perfil: nobleza, veinte; clero, seis; funcionarios, dieciséis; licenciados, abogados y médi$\cos$, doce; profesiones mercantiles y artesanos, seis, otros titulares sin profesión declarada, ocho. Un superficial repaso de ciertos fondos libreros ayudan a

73 BouZa ÁlvareZ, Fernando J.: «La fortuna historiográfica de Felipe II entre lo siglos XVI y XX. Pérdida y recuperación de la personalidad histórica del Rey Católicon; en El Escorial. Biografía de una época (La bistoria). Madrid, 1986, p. 313.

74 Del extenso texto de Cabrera sólo se publicó la historia del rey hasta la anexión de Portugal, el resto, la edición completa, no vería la luz hasta 1876-1877.

75 Cfr. GarCía CÁRCEL, Ricardo: «Felipe II y los historiadores del siglo XVII», en Vivir el Siglo de Oro. Poder, cultura e historia en la época Moderna. Estudios en homenaje al profesor Ángel Rodríguez Sánchez, Salamanca, 2003, p. 297.

Hispania, LXV/3, núm. 221 (2005) 877-938 
hacernos una idea de las aceptables posibilidades de venta de algunas de estas obras: hasta doce ejemplares del Nobiliario genealógico de los reyes y títulos de España de Alonso López de Haro, valorados en 390 reales, quedaron en las estanterías de la tienda de Miguel Martínez (1629). En la de su colega Vidarte (1624) se relacionaron 24 Discursos de la nobleza de España de Moreno de Vargas, encuadernados en pergamino y valorados en 96 reales.

Además, sin contar con otras grandes recopilaciones como la de Hernando del Pulgar: Claros varones; la Suma de varones ilustres de Juan Sedeño, o las muy acreditadas Genealogías italianas de Giovanni Boccaccio y Francesco Sansovino, junto a portuguesas como la de Duarte Nunes de Leam y otras francesas de Guillaume Rouillé, Philippe de Comines o Bertrand d'Argentre, podrían añadirse los dos tratados propiedad, entre otros, de Brianda de la Cerda, duquesa de Béjar (1602), Ana de Salcedo (1611), Juan de Acuña, marqués del Valle (1616) y Juan Hurtado de Mendoza y de la Vega (1624): Tratado de la nobleza de fray Juan Benito de Guardiola (Madrid, 1591) y el Libro de la buena educación $y$ enseñanza de los nobles de Pedro López de Montoya (Madrid, 1595). La Nobleza virtuosa escrita por doña Luisa María de Padilla, condesa de Aranda, (Zaragoza, 1637), junto a La genealogía della gloriosissima casa d'Austria de Girolamo Bossi (Venecia, 1560) se registraron, por ejemplo, en el inventario de libros del licenciado Ochoa de Madariaga (1642). Una «Genealogía de los condes de Flandes» (probablemente la escrita por Olivario Vredrio), junto a otro libro escrito en alemán sobre las "Armas de los príncipes del Imperio», más el «Catálogo de los duques y condestables de Francia» se relacionaban en la biblioteca de Juana González de Armunia (1634), curiosamente, viuda de un miembro del Consejo de Flandes. Un manuscrito intitulado: «Jenealoxias de linajes» se almacenaba en la ilustre biblioteca del gentilhombre Fadrique Furió Ceriol (1592), mientras que otros muy parecidos intitulados: «De la genealogía» y «Libro de los linajes» encontramos en las menos sobresalientes del platero Joaquín del Trejo (1597) y del archero Miguel de Prete (1644).

El intento de diferenciación cultural protagonizado por algunos juristas como Jerónimo Ximénez Marcilla (1615) también se vio reflejado en determinadas lecturas profesionalizadas como el Tractatus de Hisparorum nobilitate de Juan García de Saavedra (Alcalá, 1597), o el de Luis de Molina, De Hispanorum primogeniis (Alcalá, 1573). Una Defensa de los estatutos y noblezas españoles de Jerónimo de la Cruz (Zaragoza, 1637) fue con seguridad un texto en más de una vez consultado por el marqués de Campotéjar (1643), su propietario.

También algunos reconocidos biógrafos de su tiempo como Cristóbal Suárez de Figueroa o Luis de Belmonte Bermúdez se dedicaron a plasmar los hechos y hazañas de avanzados representantes de la nobleza como el marqués de Cañete. Estas encomiásticas historias, junto a los muy extendidos: Compendio de algunas bistorias de España... y noticia de la antigua familia de los Girones de Jerónimo Gudiel (Alcalá, 1577); Historia del fortíssimo y prudentíssimo capitán don Hernando de Ávalos, marqués de Pescara... de Pedro de Vallés (Zaragoza, 1557) o el de menor reclamo 
Diego Salazar de Mendoza: Crónico de la excelentísima Casa de los Ponces de León (Toledo, 1620) se distribuyeron en nuestra ciudad sin aparentes diferenciaciones entre la totalidad de los ambientes lectores. No obstante, un libro manuscrito titulado: «Descendencia de la Casa de Velasco» era propiedad de Mariana de Zúñiga y Velasco, condesa de Nieva (1628), y uno de similar título: «Historia del linaje de los Velasco» hallamos en la biblioteca del licenciado del consejo de Su Mag. y caballero de Santiago Gaspar de Vallejo Alderete (1623). La traducción del portugués al castellano que realizó Juan Ochoa de la Salde de la obra de Marino Barlezio: Cbrónica del esforzado príncipe y capitán Iorge Castrioto (Lisboa, 1588) tuvo ocasión de llegar a leerla el caballero de Santiago don Juan de Castañeda (1628). Unos «Linages de Soria», así citado, hallamos de forma exclusiva en la biblioteca de Francisco de Molina y Medrano (1625) que bien pudiera hacer referencia a la Información de derecho sobre la nobleza de Francisco Mosquera de Barnuevo en donde se trata de la antigua notoriedad de los doze linages de Soria.

Otra nutrida legión de obras de variado argumento: viajes, visitas y recibimientos reales, fiestas y demás acontecimientos familiares relacionados con Felipe II y su familia se alternan de forma más o menos visible en nuestra documentación. En general son escritos breves y sin grandes aspiraciones literarias, a excepción del extenso y bien documentado: Felicísimo viaje del príncipe don Felipe... a Alemania...(Anvers, 1552) de Juan Cristóbal Calvete de Estrella, que despertó un significativo interés entre todos los grupos alfabetizados de la ciudad, eso sí, siempre mejor relacionado en los inventarios de la segunda mitad del siglo XVI (71 por ciento) que en los analizados hasta 1650. Un dato absoluto son los 41 inventarios particulares que incluyen la obra de Calvete y en los que tan sólo 12 tienen fecha posterior a 1601. Una mínima muestra de poseedores de esta obra estaría compuesta por Alvar. Pérez de Loarzes, contador de la Inquisición (1555), Joan de Ibarra (1585), Gabriel de Zayas (1592), el médico de Felipe II Juan Simón de Álava e Ibarra (1595), y los contadores reales Pedro de Illán de Liébana (1594), Cristóbal González Cossío de la Hoz (1636) y Pedro de Granada (1643). Un «Viaje del príncipe» tasado en 12 reales es el único libro no religioso que hallamos en la librería del clérigo Carlos de Acuche (1596).

Pese a que la curiosidad historiográfica del lector medio respecto de la figura y época filipinas sea prácticamente muy análoga a la que vimos con Carlos $\mathrm{V}$, acaso se perciba una mayor inclinación hacia los acontecimientos inmediatos y de actualidad que, en realidad, no eran otros que aquellos que más podían afectarle y estaba viviendo: guerras de Flandes, la incorporación de Portugal, la cristiandad frente a la amenaza turca, los conflictos contra los moriscos de las Alpujarras, las alteraciones de Aragón, etc. Asuntos todos con un importante contenido militar que gozaron de un notable florecimiento, aún más si cabe, favorecido por la circunstancia de ser una parte de la historiografía que, en palabras de Fueter, no arriesgaba un conflicto con la censura al no entrar en cuestiones dogmáticas, incluso en otras de naturaleza política ${ }^{76}$.

76 FUETER, Eduardo: Historia de la bistoriografía. $\therefore$ op. cit., p. 261.

Hispania, LXV/3, núm. 221 (2005) 877-938 
Una primera conclusión respecto de esta concreta producción historiográfica -a menudo prolija en detalles, pero al mismo tiempo clara y firme en su conjunto- permite hablar de unos planteamientos en actitud, estilo y forma muy similares a los ya analizados. A pesar de las nieblas que llegaron a ensombrecer algunos episodios concretos, en general, se mantuvo la tendencia a reproducir sin alteraciones notables la tradición historiográfica de corte partidista, triunfalista y esencialista en la que España y sus reyes, indiscutiblemente, seguían ejerciendo una misión universal.

En cuanto a la conciencia histórica de estos asuntos que estaban sucediendo ${ }^{77}$ aparecen con mayor regularidad las cuestiones de política exterior que principalmente apuntaban hacia el conflicto de Flandes, las luchas con turcos y berberiscos, la anexión de Portugal, o las guerras de Francia, mientras que en asuntos internos contabilizamos la guerra de Granada como uno de los temas de mayor atractivo entre los madrileños. Relatos en su mayoría marcados por una considerable visión histórica, gran realismo y altura literaria, reclamados por un público lector que ante todo deseaba estar informado de los acontecimientos presentes, y más aún cuando éstos estaban tratados por testigos de vista como fue el caso del soldado y diplomático Bernardino de Mendoza autor de los Comentarios de los sucedido en las guerras de los Payses Baxos (Madrid, 1592), una obra que hallamos en 42 inventarios $^{78}$, en los que, sin embargo, seis de cada diez eran de titularidad nobiliaria y altofuncionarial 79 . Una aparente preponderancia por parte de las clases altas de la ciudad que, sin embargo, bien podría matizarse comprobando los teóricamente asequibles precios de la obra (2,5 reales el ejemplar) que hallamos en la tienda de Mariana Hernández (1607); o en la de Jusepe Vidarte (1.624) cuyos ejemplares encuadernados en pergamino no superaban los diez reales. Otro título que prácticamente sostiene los mismos porcentajes de posesión (aunque, eso sí, en menos de la mitad de bibliotecas que el caso anterior) es el de Antonio Trillo: Historia de la rebelión y guerra de Flandes, también editada en Madrid en 1592.

Referentes al conflicto de los Países Bajos circularon otros textos que ofrecieron testimonios suficientes para mantener vivo ese interés y conocimiento por las cosas presentes. El licenciado Diego Altamirano (1642) guardaba en el momento de su muerte unas Alteraciones de los Estados de Flandes (Madrid, 1601) de Antonio Martín del Río; y el criado real Francisco Ruiz de Ondárroa (1629) pudo leer Los sucesos de Flandes y Francia, del tiempo de Alexandro Farnese escrito

77 Vid. CEPEDA ADÁN, José: «La Historiografía», op. cit. p. 571.

78 Los datos recogidos por Manuel Peña demuestran, por el contrario, que el conflicto de Flandes fue poco atractivo para los lectores barceloneses del siglo XVI. PEÑa DíAZ, Manuel: El laberinto de los libros... op. cit., p. 151. Por su parte, Antonio Espino asegura que la repercusión sobre el papel de lo ocurrido en los Países Bajos sólo comenzó a producirse en los últimos años del Quinientos. ESPINO LÓPEZ, Antonio: Guerra y cultura..., op. cit., p. 197.

79 En la biblioteca de Fadrique Furió Ceriol se conservaba unos Comentarios de las guerras de los Países Bajos de Bernardino de Mendoza, obra de la que fue censor. 
por Alonso Vázquez. Las Guerras de Flandes de Francisco Lanario y Aragón y unas «Relaciones de Flandres» formaron parte de las lecturas del doctor Sancho de Moncada (1644) ${ }^{80}$. Una «Respuesta al manifiesto de Flandes» ${ }^{81}$ (sic) se anotó en el recuento de libros del guadarnés Agustín Valverde (1644), mientras que una edición Delle guerre di Fiandra (Amberes, 1609) de Pompeo Giustiniano encontramos entre los libros del licenciado Juan Ochoa de Madariaga (1642). Aparecen igualmente otros originales como el Sumario de la guerras civiles y causas de la rebelión de Flandes de Pedro Cornejo (Lyon, 1577) en colecciones de titularidad nobiliaria como las de Ana de Toledo (1596), Juan de Acuña (1616) y Juan Hurtado de Mendoza y de la Vega (1624). Un «Sitio y presa de Ostende» se anota en el recuento de libros de Gabriel Lasso de la Vega (1615), tal vez La nouvelle Troye ou memorable bistoire du siege d'Ostende de Henry Haestens. La popularidad que gozó esta temática permitió la traducción de textos como el de Pierre Mathieu: Historia de las guerras de Flandes... traducido al castellano por Juan Pablo Mártir Rizo, (Valencia, 1627) y que se vendía al módico precio de un real en la librería de Martín de Beva (1635).

Pero como se sabe la España de Felipe II mantuvo vivos otros conflictos que desde el punto de vista editorial también lograron importantes cotas de negocio. La consulta de los inventarios muestra dos títulos que destacan sobre los demás: los Cinco libros de la bistoria de Portugal y conquista de las Islas de los Açores en los años 1582 y 1583 de Antonio de Herrera Tordesillas (Madrid, 1591) y la Historia de la guerra de Granada que escribió Diego Hurtado de Mendoza. Ambas, a lo largo de sus correspondientes periodos editoriales, alcanzaron una acentuada y duradera atención por parte de la mayoría del público lector madrileño que, pese a la coincidente excepción de los menores porcentajes registrados entre clérigos y profesiones liberales, su reparto general por grupos sociales responde a tal heterogeneidad que hace casi inútil cualquier análisis de tipo comparativo. De la Historia de Herrera contabilizamos 47 títulos plenamente identificados de los que, curiosamente, algo más del setenta por ciento corresponden a inventarios fechados antes de 1630, produciéndose un relativo pequeño vacío en las dos siguientes décadas.

Por su parte, la obra de Hurtado de Mendoza conoció dos procesos de difusión: uno inicial a través de copias manuscritas y otro impreso a partir de 1627 , fecha de su publicación, es decir casi medio siglo después de que fuera redacta$\mathrm{da}^{82}$. Tan sólo recogemos en las bibliotecas de Adrián Calvete (1612) y Gaspar Vallejo Alderete (1623) noticias manuscritas de los «Sucesos de la guerra de Granada de Mendoza». Descripciones como la intitulada: «Obras de don Diego de Mendoza» recogemos entre los libros de Rodrigo Tello de Guzmán, co-

80 A.H.P.M., protocolo 6639, (1644).

81 Tal vez por una inadvertencia del escribano de turno se estaba refiriendo a la Respuesta al manifiesto de Francia, impreso en Madrid por Francisco Martínez en 1635.

82 ALBORG, José Luis: Historia de la literatura española: Edad Media y Renacimiento, I, Madrid, 1975, pp. 991-993.

Hispania, LXV/3, núm. 221 (2005) 877-938 
mendador de Alcolea (1626). El resto de entradas impresas, hasta 41, las vemos mayoritariamente distribuidas entre nobles y alto funcionariado ( 57 por ciento). El porcentaje de posesión del estamento eclesiástico apenas llega al siete por ciento, mientras que oficios artísticos, servicio doméstico, mercaderes y artesanos alcanzan el once por ciento. Sumamos un punto menos entre los licenciados, abogados, maestros, médicos, boticarios, etc. y del resto de grupos el reparto queda muy difuminado entre inventarios sueltos, en su mayoría sin identificación socio-profesional.

A diferencia de los textos anteriores, encontramos la Historia de los sucesos de Francia de Antonio de Herrera, impreso en Madrid por Lorenzo Ayala en 1598, y la obra de Pedro Cornejo: Compendio de la Liga y Confederación francesa (Bruselas, 1591) que tuvieron una presencia bastante menos abierta. En ambos casos la nómina de poseedores se presenta muy puntual, poco representativa e indistinta desde el punto de vista socio-profesional. En total 12 ejemplares pertenecientes a ciudadanos como don Fernando de Eraso (1606) y Gabriel Lasso de la Vega (1615), el boticario Diego de Cortavila (1615), el registrador y chanciller mayor del rey Jorge Olalde Vergara (1618) y contadores como Juan de Aguiar (1634) o Pedro Illán (1594). Un libro intitulado «Monarquía de Francia» estuvo en poder del agente de negocios Luis Jerónimo de Sevilla (1615). Y otro intitulado: «Historias francesas de Forsari» (que identificamos con el de Jean Froissart, Chroniques de France) lo hallamos exclusivamente en la biblioteca de la condesa de Nieva Mariana de Zúñiga (1628). La traducción que hizo Juan Pablo Mártir Rizo de la obra de Pierre Matthieu (Pedro Mateo), impresa en Madrid por Diego Flamenco en 1625 con el título de Historia de la muerte de Enrico el Grande, quarto rey de Francia, estaba en posesión del platero Bartolomé Rodríguez (1638) y de Pedro de Baeza (1648).

Llegados aquí, y a pesar de que haga referencia a otra época - la de los últimos días del reino granadino hasta la conquista en 1492 por los Reyes Católicos- - conviene mencionar la obra de Ginés Pérez de Hita: Historia de los bandos de Zegríes y Abencerrajes, más conocida como Guerras civiles de Granada, editada en 1595 en Zaragoza. De este singular relato, a caballo entre la realidad histórica y el episodio novelado, algunos datos recogidos permiten confirmar su aceptable difusión: encontramos la obra entre los libros del licenciado Camilo Negrón (1607) y en los de las damas Lucía de Toledo (1634) y Leocadia Enríquez (1644). Dos ejemplares poseía el médico Luis de Rivera (1608), y hasta tres hallamos en las bibliotecas del licenciado Lorenzo Polo (1611) y del duque de Rioseco Juan Alfonso Enríquez (1647). En la tienda de librería de Mariana Hernández (1607) se hallaron, aún sin vender, 22 volúmenes de la obra de Pérez de Hita a real y medio la unidad; y en la de su colega Antonio Rodríguez (1623) se enumeraron hasta siete volúmenes en octavo, sin que ninguno sobrepasara los diez reales. Por su parte, en la almoneda celebrada en la plazuela de Santa Cruz tocante a los libros del escribano Miguel Rodríguez (1634) se remataron en Matías de Corcuera unas "Guerras civiles de Granada» por las que pagó 4 reales. Su circulación también llegó hasta los sencillos in- 
ventarios del barbero y cirujano Domingo del Campo (1632), del boticario Diego de Cortavila (1615) o del maestro Juan Gurín (1614).

Otra copiosa y variada legión de títulos de muy desigual valor histórico y literario referidos a concretos sucesos particulares permiten especular acerca de ciertos intereses de lectura que, de algún modo, evalúan la concreta conciencia y realidad del mundo que se estaba viviendo. Los vemos en nuestros inventarios citados con relativa regularidad, en la mayoría de las ocasiones de forma abreviada o haciendo una mínima referencia al autor. Una pluralidad de obras que tan sólo permite revelar particularidades de posesión y no distinciones entre los grupos socio-profesionales. Al mismo tiempo, un mínimo análisis alcanzaría a generalizar su escasa continuidad a pesar de aludir a señalados acontecimientos como el narrado por Fernando de Herrera: Relación de la guerra de Chipre y sucesso de la batalla naval de Lepanto (Sevilla, 1572) o el mismo de Jerónimo de Corte Real: Felicísima victoria concedida del cielo al señor don Juan de Austria en el golfo de Lepanto (Lisboa, 1578), y, en menor medida, el Compendio bistórico delle guerre últimamente successe tra Christiani, \& Turchi de Cesare Campana (Venecia, 1597), un libro, éste último, no demasiado difundido en Madrid que tan sólo encontramos en siete bibliotecas, entre otras las del ciudadano Luis Jerónimo de Sevilla (1615) y el secretario real González de Heredia (1611).

La lectura que se hizo de títulos no menores como la Historia de la rebelión y castigo de los moriscos (Málaga, 1600) de Luis del Mármol Carvajal, el Discurso y sumario de la guerra de Portugal y sucesos de ella (Zaragoza, 1581) de Francisco Díaz de Vargas, la Historia de la guerra y presa de Africa (Nápoles, 1552) de Pedro Salazar y, de este mismo, su posterior Hispania victrix, (Medina del Campo, 1570), además de otras suficientemente presentes: Conquista de África de Diego de Fuentes; Historia de la guerra entre turcos y persianos de Giovanni Tomasso Minado, o los Comentarios de los sucesos de Aragón de 1591 y 1592 de Francisco Gurrea, tampoco permite establecer la sistematización de los gustos lectores ni su clasificación socio-profesional. Recordemos que entre los escasos libros del capellán Gonzalo de Peña Carrillo (1620) se anotaba el poco solicitado texto de Francesco Balbi de Corregio: La verdadera relación de todo lo que este año de MDLXV ba sucedido en la isla de Malta (Alcalá, 1567). Las Guerras de Malta y toma de Rodas... de Diego de Santisteban Osorio, impresa en Madrid en el taller del licenciado Várez de Castro en 1599 se vendían a tres reales en la librería de Mariana Hernández (1607).

Todas estas obras, independientemente de su mayor o menor posesión, constituyen una realidad lectora que explica inmejorablemente esa atmósfera bélica que embebió (sobre todo durante las tres primeras décadas del siglo XVII) a un importante número de lectores madrileños, eso sí, caracterizados más que por su homogeneidad sociológica por un desigual y personalizado consumo. Por ejemplo, llama la atención el hecho de que mientras en el fondo librero de Juan Hasrey (1615) apareciera hasta 123 ejemplares del Comentario do cerco de Goa de Antonio de Castilho (Lisboa, 1573), en el repaso de inventa- 
rios de bibliotecas fechados entre 1601 y 1620 tan sólo se cite formalmente en ocho ocasiones.

Más arriba tuve ocasión de advertir la frecuencia con que la función de historiar iba aparejada a la de ensalzar la imagen monárquica. Ciertamente, la crecida fama que rodeó a Felipe II se proyectó aún más allá de los exclusivos relatos de su vida y hechos. Los episodios que se escribieron sobre su enfermedad y muerte fueron asimismo objeto de una gran atención por parte de amplios sectores alfabetizados de la ciudad, desde nobles a artesanos. Pero tal vez su éxito no sólo hay que atribuírselo a la personalidad del rey, sino al alto contenido virtuoso y moralizante, a modo de lección de bien morir, que tenían dichos relatos. Pedro de Lezcano Monroy (viudo) (1616), el guantero Francisco Moreno (1622) y el contador del consejo de Castilla Juan Cortés de la Cruz (1651) tenían entre sus libros el de fray Antonio Cervera de la Torre: Testimonio auténtico y verdadero de las cosas que pasaron en la muerte del rey don Felipe II (Valencia, 1599). De igual forma el agente de negocios de los Fúcares Bernardo Slisnequer (1612) guardaba en su estudio «dos muertes del rey don Felipe segundo" que con seguridad hacían referencia a la de Cervera. Al precio de tres reales se ofrecían en la tienda de la librera Mariana Hernández (1607). Una vez más, don Antonio de Borja (1614), don Juan Hurtado de Mendoza (1624) y don Juan de Acuña (1616) eran poseedores en el momento de su fallecimiento del muy difundido Elogio a las esclarecidas virtudes... del rey N. S. Don Felipe II de Cristóbal Pérez de Herrera (Valladolid, 1604). Para terminar esta relación, un apunte sobre la censurada Relación de la muerte y bonras fúnebres del serenísimo principe don Carlos, (Madrid, 1568) conservada en los anaqueles de las selectas bibliotecas de Juan de Ovando, presidente del consejo de Indias (1575), y Pedro Rodríguez de Alcántara, regidor de Madrid (1596), éste último, verosímilmente, uno de los promotores del encargo de la obra que el ayuntamiento de Madrid hizo a Juan López de Hoyos, su autor.

Si atendemos a los datos globales, y en contraste con los recogidos para los reinados del siglo anterior, la historiografía dedicada a los reyes y época de $\mathrm{Fe}$ lipe III y Felipe IV proyectó en la ciudad una mucho menor atención lectora, circunstancia, sin embargo, que no impide especular sobre una posible y más amplia circulación.

En las bibliotecas de los círculos más selectos del entramado social madrileño encontramos tan sólo nueve ejemplares del Viaje de Felipe III a Portugal (Madrid, 1612) de Joan Baptista Lavaña, y ninguno en las tiendas de librería, una debilidad de referencias concretas que si comparamos con otras circulaciones no representan, obviamente, un factor de amplia divulgación. Una solitaria Relación de las pazes entre España e Inglaterra de Juan de Ledesma (Málaga, 1605) descubrimos entre los libros del agente de negocios Bernardo Slisnequer (1612), y en esta misma situación habría que incluir títulos como la Entrada que bizo en París el Duque de Pastrana (Madrid, 1612) o el Sítio y socorro de Fuenterrabía y sucesos del año 1638 de Juan de Palafox (Madrid, 1639) que hallamos 
excepcionalmente en las bibliotecas de Gabriel Lasso de la Vega (1615) y del fiscal Diego de Altamirano (1642), respectivamente. Algunos asientos más se contabilizan de la Relación de los sucedido en Valladolid por el nacimiento del príncipe Felipe IV (Valladolid, 1605), y, sobre todo, de la Historia de don Felipe IV de Gonzalo de Céspedes y Meneses (Barcelona, 1634) que se hace ver en una docena de bibliotecas de titularidad variada como las del escribano Miguel Rodríguez (1634) y del noble Pedro de Granada (1643).

Aún más puntuales y sin apenas proyección en el tiempo encontramos referencias sobre determinados asuntos políticos del momento. La Defensa de España contra las calumnias de Francia de José Pellicer de Tovar (Venecia, 1635), o la Respuesta al manifiesto de Francia (Madrid, 1635) que encontramos respectivamente entre los libros del platero Bartolomé Rodríguez (1638) y en la colección del servidor real Agustín Valverde (1644). El Marte francés de Cornelio Jansenio lo vemos anotado en los inventarios del licenciado Ochoa de Madariaga (1642), y en el de la biblioteca del doctor Sancho de Moncada (1644), la de éste último con dos ediciones: una en romance y otra en latín ${ }^{83}$.

Los afanes y sueños que muchos madrileños encontraron en la historiografía «americana» se contrastan con las exclusividades que vimos antes. Sin caer en falsas generalizaciones, la práctica totalidad de las grandes historias que se escribieron sobre el descubrimiento y conquista del Nuevo Mundo - sin apenas salvedades- aparecen en nuestras bibliotecas. Quizás la principal explicación estuvo en el equilibrio textual que se planteó entre el relato histórico y la descripción geográfica, naturalista y etnográfica, muy del gusto de la época. Las nuevas narraciones manifestaron no sólo la veraz historia de los hechos ocurridos, sino el asombro producido por la percepción de las nuevas tierras conquistadas como lugares extravagantes y llenos de inesperadas maravillas.

A tenor de la precisión con que se observaron y expusieron todas estas «novedades y extrañezas» cabría destacar, en principio, dos obras muy cercanas a la historia natural que causaron un gran impacto en la ciudad: la de Gonzalo Fernández de Oviedo: Historia general y natural de la Indias, islas y tierra firme del mar océano, (Sevilla, 1535), y la del jesuita José de Acosta: Historia natural y moral de las Indias (Sevilla, 1590) ésta última calificada por Sánchez Marcos como la más «lúcida e influyente descripción — hasta fines del siglo XVIIIde las sociedades inca y azteca» ${ }^{84}$. También Esteve Barba ha comparado ambas llegando a la conclusión de que Oviedo gana a Acosta en la descripción individual de las especies, y Acosta aventaja a Oviedo en la amplia concepción e interpretación de los hechos ${ }^{85}$.

En cualquier caso, la difusión en Madrid del texto de Acosta, a pesar de algunos altibajos, fue ligeramente más pródiga en las siguientes tres décadas a su

83 A.H.P.M., protocolo 6639, (1644).

84 SÁNCHEZ MARCOS, Fernando: «La historiografía sobre la Edad Moderna», en José Andrés Gallego (coord.), Historia de la bistoriografía española, Madrid, 2003, p. 134.

8s Esteve BARBA, Francisco: Historiografía..., op. cit., p. 117 
publicación que durante el resto de la primera mitad del XVII, mientras que el libro de Oviedo, aun teniendo su grueso de posesión durante el siglo XVI, mantuvo su continuidad prácticamente inalterable hasta 1650 . Como no pudo ser de otro modo, ambos gozaron de una reconocida aceptación social, particularmente entre mercaderes, artistas, funcionarios y profesionales de la medicina. Todavía se podían adquirir en 1624 diecisiete "Historia de las Yndias de Acosta» en la tienda del librero Jusepe Vidarte a cuatro reales la copia en papel y a seis la encuadernada. El único libro inventariado entre los bienes de Juan de Heredia, teniente de correo mayor del rey (1597) fue un "Acosta». De otras obras del célebre jesuita, personajes como Diego Altamirano (1642) y el doctor Sancho de Moncada (1644) eran propietarios en exclusiva De Natura Novi Orbis (Salamanca, 1589). Y respecto de Oviedo tan sólo recordar la particularidad del inventario de los bienes del regidor Pedro Rodríguez de Alcántara (1596) en el que aparece un curioso manuscrito intitulado " $4^{\mathrm{a}}$ pte. de la Natural y General historia de las Yndias».

Nuestra imprenta permitió alargar y ensanchar el triunfo del modelo historiográfico conocido como Cronística de Indias, y que éste generara nuevas producciones de gran aceptación entre buena parte de la sociedad alfabetizada de la Europa occidental del momento ${ }^{86}$. Un influjo para la creación historiográfica que incluso también marcó normas entre la mayoría de los historiadores humanistas del continente, acaso por la característica de ser unos relatos con una más vivaz y realista estructura narrativa, escritos al ritmo de los acontecimientos, muy en consonancia con el modelo propuesto por Herodoto ${ }^{87}$.

Por los resultados de nuestra encuesta, y desconsiderando algunos, no pocos, títulos encontrados con el vago enunciado de «Historia de Indias», una de las obras que mayor proyección alcanzó entre nuestros lectores fue la Historia general de Indias de Francisco López de Gómara, (Zaragoza, 1552) dedicada a Carlos V, y en la que relata casi en exclusiva los cuatro viajes de Cristóbal Colón. Representantes de la práctica totalidad de la jerarquía cultural de la ciudad poseyeron alguna copia de este título. Del resto de grupos, factiblemente, podemos hablar de una más que aceptable pluralidad. La nómina de sus poseedores (un 23 por ciento sin perfil sociológico concreto) refleja esa multiplicidad de la que hablábamos. En los inventarios de las tres primeras décadas del siglo XVII contabilizamos dieciséis entradas de su Historia, pero es en el periodo 1550-1600 con 36 citas donde se advierte el principal auge que tuvo la obra en

86 Sobre los libros de historia americana en el tráfico comercial de la Carrera de Indias, véase el reciente trabajo de RUEDA RAmírez, Pedro J.: Negocio e intercambio cultural: el comercio de libros con América en la Carrera de Indias (siglo XVII), Sevilla, 2005, en especial el capítulo VIII.

87 Cfr. MORADIEllos, Enrique: El oficio de bistoriador, Madrid, Siglo XXI, 1994, p. 28. Para Esteve Barba cada historiador indiano era como un nuevo Herodoto: «triple padre a un tiempo de la Historia, de la Etnografía y de la Geografía, a la vez alborozado y extrañado ante el contacto imprevisto de los nuevos aspectos que se van presentando a sus ojos", vid. ESTEVE BARBA, Francisco: Historiografía..., op. cit., p. 11. 
nuestra ciudad. Algo menores cuotas de consumo notamos de su otra gran aportación historiográfica consagrada a relatar las proezas de Hernán Cortés. En efecto, a pesar de gozar de una significativa reputación su Historia de México (Zaragoza, 1553) no llegó al éxito cosechado por la anterior, pero sin embargo se proyectó mucho más a lo largo de la primera mitad del siglo XVII. Sólo para este tramo descubrimos varios ejemplos: "dos Historias de Méjico, de Gómara, en octavo, en cuatro reales», estaban en los anaqueles del fondo librero de Antonio Rodríguez (1623), y otros dos se relacionan en el inventario del secretario Jerónimo González de Heredia (1611). Con una copia, la nómina sería larga de relatar, tan sólo elegimos los casos de del secretario real Juan Fernández de Madrigal (1632), del capellán Gonzalo de Peña Carrillo (1620), Francisco Ruiz de Ondárroa, ayuda de guardajoyas (1629), y de las damas Francisca de la Peña (1609), Juana de Mújica (1617), Mariana de Montaña (1630) y Lucía de Toledo (1634).

Otra fecunda relación de los hechos de Cortés en Nueva España fueron narrados por Gabriel Lasso de la Vega en La Mexicana (Madrid, 1588) una obra que interesó, entre otros, al arriba citado Juan Fernández de Madrigal, y al regidor Pedro Rodríguez de Alcántara (1596). De similar sustancia a la Historia medicinal de Nicolás Monardes fue la mucho menos frecuente obra de Diego Cisneros: Sitio, naturaleza y propiedades de la ciudad de México (México, 1618) que hallamos de forma exclusiva en la biblioteca del licenciado Juan Ochoa de Madariaga (1642).

Dentro de las crónicas oficiales, y como complemento a la escrita por Gómara, otro singular texto que satisfizo con creces las aficiones del gran público lector madrileño fue el elaborado por el segoviano Antonio de Herrera Tordesillas: Historia general de los hechos de los castellanos en las islas y tierra firme del mar Océano, impresa en Madrid por la Imprenta Real en 1601. Eso sí, contabilizamos un descenso del 18 por ciento respecto de la obra de López de Gómara aunque en su favor cabe advertir su mucho más jerárquica y selectiva posesión alcanzando mejores porcentajes entre la nobleza y altos servidores del rey, no tanto así entre los eclesiásticos.

Compuestas dentro de ese trato lector, alejado de falsas apariencias, hubo otras muchas historias que igualmente colmaron nuevas apetencias. El marqués Pedro de Granada (1643) poseía una «Historia de Indias de Figueroa» posiblemente relacionada con algún escrito misional del jesuita Francisco de Figueroa dedicado a los indios del Amazonas. Citada como «Descrición sumaria de las Indias" (tal vez una distorsión de los títulos de las obras de Herrera Tordesillas o de Vargas Machuca) hallamos referencias en los inventarios de Juana de Mújica (1617), y del licenciado Juan Ochoa de Madariaga (1642).

En este grupo de obras es de notar la escasísima presencia de la Relación de la destruyción de las Indias de Bartolomé de las Casas, un título que tan sólo encontramos entre los escasos libros del escribano Francisco de Sigüenza (1625). A su vez, una "Descubrición de las Yndias, en ytaliano" así descrita, localiza- 
mos entre las lecturas de Gabriel de Zayas (1592). Por su parte, Juan de Ovando (1575), junto al mercader de origen luso Andrés Barreto (1622) y el contador real Pedro Illán (1594) pudieron leer en lengua portuguesa la Historia do descobrimento y conquista da India pelos portugueses (Coimbra, 1554) de Fernando Lopes Castaheda. Una «Milicia indiana» que identificamos con la obra de Bernardo Vargas Machuca: Milicia y descripción de las Indias, (Madrid, 1599) aparece en el inventario de los libros de criado de Su Mag. Francisco Ruiz de Ondárroa (1629). Como remate, el escrito de Gregorio García: Origen de los indios de el Nuevo Mundo, (Valencia, 1607) le vemos relacionado en el catálogo de la biblioteca del capellán real Gonzalo Peña Carrillo (1620). Y para terminar, y como ejemplo de la versatilidad de lecturas que encontramos, llamamos la atención sobre la Relación y Comentarios (Valladolid, 1555) del viaje de Alvar Núñez Cabeza de Vaca por América del Norte y la descripción de su segunda expedición a las Indias que localizamos en la modesta biblioteca del boticario Diego de Burgos (1570) y en las más cumplidas de Juan de Ovando (1575), con dos ejemplares, y en la que conservó en Madrid Pedro Juan de Lastanosa (1576)

Composiciones históricas dirigidas a ámbitos e historias más localizados también aparecen frecuentemente citadas, pero a veces de forma tan apresurada que resulta casi imposible determinar su edición o autoría, por ejemplo las referidas al virreinato del Perú de autores como Agustín de Zárate, Diego Fernández de Palencia o Pedro Cieza de León. De los 7.1 ejemplares que en conjunto hemos contabilizado, en torno al 65 por ciento corresponden a los dos estamentos privilegiados - pero con notable diferencia (ocho de diez) a favor de la nobleza-, mientras que del resto algo más de la mitad importa a funcionarios y a oficios artísticos, y el sobrante, a sectores mercantiles y artesanales. Sorprenden las escasas noticias que aparecen en las bibliotecas de abogados y tampoco demasiadas entre el colectivo sanitario.

Algunas referencias más permiten hacerse una idea del considerado interés que despertaron otras relaciones de la conquista del Perú: por ejemplo tropezamos con una edición de la Reducción universal de todo el Perú y demás Indias de Miguel de Monsalve (Lima, 1602) perteneciente al guantero Francisco Moreno (1627). Unos Varones ilustres del Nuevo Mundo de Fernando Pizarro y Orellana hallamos en la biblioteca de Diego Altamirano (1642) que, a su vez, guardaba una Historia general del Perú (Córdoba, 1617) del Inca Garcilaso de la Vega. De este mismo autor, los Comentarios reales que tratan del origen de los yncas (Lisboa, 1609) estaban en posesión del funcionario real Francisco Ruiz de Ondárroa (1629) y del guardajoyas y tesorero del duque del Infantado Tomás de Arcos (1631).

Hasta 21 copias de la "Historia del Perú» valoradas en 105 reales se vendían en la tienda de Miguel Martínez (1629). Y para rematar, tan sólo referirnos a un curioso «Memorial de las cosas de las Indias dado a Su Mag. por fr. Juan de

${ }_{88}$ Cfr. Alvar EzQuerra, Alfredo y Bouza Álvarez, Fernando J.: «La librería de don Pedro Juan de Lastanosa ...», op. cit., p. 142.

Hispania, LXV/3, núm. 221 (2005) 877-938 
Santander de la orden de San Fco.» archivado junto a otros papeles viejos entre los bienes de doña Elvira de Guzmán, dama de la reina (1641).

\section{Nuevas evocaciones y conocimientos del mundo: los libros de viajes}

El espíritu humanista se vio seducido por las nuevas sensaciones surgidas a raíz de los grandes descubrimientos geográficos que estaban cambiando la imagen del mundo. Entre otras coyunturas, por la novedad que trajo el auge en los contactos mercantiles, culturales y de todo tipo entre países, y por el sustancial adelanto en los conocimientos que se aplicaron a la geografía tradicional.

Los resultados prácticos lograron a través de un torrente de publicaciones sobre cosmografías y relatos de viajes prosperar con fuerza e instalarse en la gran mayoría de las conciencias de la sociedad europea, principalmente, a partir de la segunda mitad del siglo XVI.

De forma equivalente a lo que vimos con la historiografía indiana, en resumen, es el momento en el que a través de una completa exposición acerca de diferentes realidades culturales, de nuevas descripciones geográficas de países; regiones, incluso de continentes, la curiosidad por demostrar la primicia y amenidad que conllevaba la riqueza del mundo se mantuvo en primera línea de atención. Quizás uno de los objetivos más sugerentes consistió en presentar a los lectores todo lo que desde una finalidad cultural pudiera simbolizar noticias insólitas o exóticas de tierras y pueblos lejanos. Y de todo ello, como no, se creó un más que multiplicado eco en buena parte de nuestras bibliotecas, principalmente, como dije, fechadas a partir de mediados del XVI, y de forma algo más renovada hasta los años cincuenta de la siguiente centuria.

Como contemporáneo de esos años, el mismo Baltasar Gracián pudo llegar a convencerse de que «todo lo pasado parece mejor y todo lo distante es más estimado» ${ }^{89}$. José Antonio Maravall, sobre esa base, alcanzó más lejos precisando que junto a la natural curiosidad de la sociedad por estas fascinantes descripciones se solapaba un cierto propósito estratégico y de utilidad política para mantenerse bien informado acerca de los aliados y posibles enemigos ${ }^{90}$. A ese respecto, nos preguntamos si sería mucho suponer que las relaciones del «Reyno de Moscovia»; las del "Reyno de Sicilia», más la "Relación histórica del Regno de Suecia» enumeradas en la selecta biblioteca de Juana de Mújica y Butrón (1617) tuvieran esos mismos propósitos coyunturales. De igual manera cabría pensar de Magno Lucenberg, apoderado de los Fúcares en la corte (1602), que guardaba en su estudio un librito de «La navegación y viage de Turquia». En ese perímetro tampoco extrañará una "Historia de Escocia» - probablemente la Historia de lo sucedido en Escocia de Antonio de Herrera (Ma-

89 Cit. por Maravall, José Antonio: Antiguos y Modernos... op. cit., p. 82.

90 Ibídem, pp. 72-83.

Hispania, LXV/3, núm. 221 (2005) 877-938 
drid, 1589) — que leyeron, entre otros, Alonso de Ercilla (1594) y el escribano Luis Juan de Escorigüela (1597). También nos interesa la exclusividad de la «Historia de las tierras y reynos de Noruega, en flamenco» que se anotó en el inventario de libros de Isabel Montero, viuda del entallador Francisco de $\mathrm{Hem}$ (1629), y de forma paralela uno de los tres libros que poseía el escribano Francisco de Rojas, referido a «la tierra de Albania». La curiosidad llegó hasta otras obras, asimismo muy específicas, como la que hallamos en la biblioteca del secretario Miguel Ruiz Azagra (1583) intitulada: «Historia de gentes septentrionales» que identificamos con la obra de Olaus Magnus: Historia de gentibus septentrionalibus (Antuerpiae, 1558), incluso la Descrittione di tutti i Paesi Bassi de Guicciardini (Anvers, 1581) propiedad del otro agente de los Fúcares, el alemán Bernardo Slisnequer (1612). Quizás mayor proximidad política contuvo la obra de Jerónimo Román, Repúblicas del mundo (Medina, 1575) cuyo éxito queda plenamente acreditado a tenor de su presencia en las colecciones de once nobles, cuatro clérigos, un catedrático, cinco licenciados, ocho altos funcionarios, cuatro mercaderes y un artesano. Hasta tres ejemplares de esta obra guardó el contador real Andrés Núñez de Azcárate (1587).

Un total de 38 ciudadanos, en su mayoría nobles y funcionarios reales como Pedro Niño de Rivera, mayordomo de la reina (1579), García Fernández Manrique, conde de Osorno (1587), Sebastián Cordero de Nevares, ayuda de cámara de Su Mag. (1588), Pedro Fernández de Castro, conde de Lemos (1606), Mariana de Montaña (1630), Felipe de Arenberg (1640), Pedro de Granada, marqués de Campotéjar (1643), el caballero de Santiago Juan de Castañeda y Ronquillo (1628), junto a otros como el escribano Luis Juan de Escorigüela (1597), el capitán Jerónimo de Soto (1630), o el capellán Gonzalo de Peña Carrillo (1620) gozaron de las excelencias bibliográficas de joyas como el Theatrum orbis terrarum (Antuerpiae, 1579) de Abraham Ortelius. La alta calidad de la obra, tanto por su contenido como por su continente, quedaba demostrada por los elevados precios que tomaba, también en las ventas de segunda mano: en la almoneda de algunos bienes de Pedro Juan de Lastanosa se vendió «Un libro intitulado Teatrum Orbis Terrarum en doscientos rreales» ${ }^{91}$.

Pero la continuidad de este singular tratado geográfico no sólo se reflejó en las bibliotecas particulares. Hasta cinco «Teatrum orteli, en romance, grandes» sin encuadernar, a 80 reales cada uno, se inventariaron en la tienda del librero Juan Hasrey (1615), en la que, asimismo, encontramos dos ejemplares del $\mathrm{Ci}$ vitates orbis terraruum de Georgius Braun, en cinco volúmenes y tasados en 100 reales, y un Atlas Minor del holandés Gerardus Mercator, sin encuadernar, en veinte reales.

Más moderada difusión que el Ortelius obtuvo el tratado geográfico de Julio Solino: De rerum orbis memorabilium (Lugduni, 1539), que, entre otros madrile-

91 Vid. Alvar EzQuerra, Alfredo y Bouza Álvarez, Fernando J.: «La librería de don Pedro Juan de Lastanosa...", op. cit., p. 115. 
ños, poseyeron el capellán mayor de las Descalzas Reales Pedro Paniagua (1614), la viuda Juana Vélez Tenorio (1638) y el boticario Juan García Comendador (1639). La traducción que de esta misma obra realizó Cristóbal de las Casas (Sevilla, 1573) estaba entre los libros de la biblioteca de Cristóbal González Cossío, (1636), contador de resultas del rey. Un solo ejemplar de la selecta Cosmographia de Sebastián Munster se cita en el inventario de la viuda Isabel Montero (1629). Hasta en nueve bibliotecas del siglo XVI, y en tan sólo cuatro del XVII hallamos referencias de la Suma de geographia (Sevilla, 1530) de Martín Fernández de Enciso, y de forma paralela, en cuatro ocasiones, a lo largo del periodo 1601-1650, aparece de la obra de Giovanni Botero: Descripción de todas las provincias y reynos del Mundo (Barcelona, 1603). Una «Geografía universal» se anota entre los escasos libros del veneciano, afincado en Madrid, Bartolomeo Rota (1608).

Los modelos propuestos se completaron, era previsible, con otros textos de autoría grecolatina. Bien es cierto, y así lo hace ver López Piñero, que el humanismo geográfico se centró principalmente en el llamado «renacimiento de Ptolomeo» ${ }^{92}$, es decir, en la recuperación y difusión de su Geografía, un tratado que, a través de nuestra particular encuesta, encontramos citado hasta en 46 bibliotecas, eso sí, de forma muy imprecisa, esencialmente aludiendo a su autor $y$, ocasionalmente, a su título. En cualquier caso tenemos que hablar de una dilatada e invariable continuidad demostrada por este famoso tratado geográfico, que por encima de otras singulares descripciones (Cosmographia de Pomponio Mela, o de Estrabón: De rerum geographicarum) permaneció entre los gustos de los madrileños plenamente vigente al menos hasta mediados del siglo XVII.

Quedémonos como muestra con tres bibliotecas muy alejadas en el tiempo y de ámbitos de procedencia muy diferentes: hasta tres ejemplares se anotaron en el inventario de los libros del presidente Juan de Ovando (1575), uno de ellos intitulado: "Geografía de Tolomeo con sus tablas y estampas». Hasta ocho obras del eminente geógrafo hallamos en la excelente biblioteca madrileña de Pedro Juan de Lastanosa (1576) ${ }^{93}$. Otro «Tolomeo escrito de mano» y en romance lo descubrimos en el inventario de bienes de dote de Elvira Dulce Forzela (1600). Y ya en los años cuarenta del siglo XVII (1644) Leocadia Enríquez, aparece como propietaria de otra copia descrita, igualmente, de forma muy lacónica.

En anotaciones referidas a libreros advertimos, por ejemplo, que un «Tolomeo en italiano" se vendía al módico precio de dos reales en el establecimiento de Antonio Rodríguez (1623). Desde un punto de vista más amplio, los datos nos confirman, no obstante, que al margen de no apreciarse notables

92 LÓPEZ PIÑERo, José María: Ciencia y técnica en la sociedad española de los siglos XVI y XVII, Barcelona, Labor, 1979, p. 213.

93 Vid. Alvar EzQuerra, Alfredo y Bouza Álvarez, Fernando J.: «La librería de don Pedro Juan de Lastanosa...", op. cit., pp. 115, 129, 132, 134, 137, 139, 147.

Hispania, LXV/3, núm. 221 (2005) 877-938 
diferencias sociales en cuanto a su posesión, de nuevo tenemos que referirnos a los porcentajes de los inventarios de la nobleza como ligeramente superiores a los del resto de grupos.

Dentro del conjunto general de estos escritos no podemos dejar de reseñar el vivaz e imaginativo viaje a Samarcanda de Ruy González de Clavijo: Historia del gran Tamorlán... (Sevilla, 1582). En todo el relato contado por el camarero de Enrique III de Castilla, según cuenta Sánchez Alonso, se infunde expectación y se ofrece certero testimonio de plantas y animales, de usos peculiares, de asuntos de comercio, de sucesos históricos, y de tradiciones ${ }^{94}$. En cuanto a su posesión lo hemos podido relacionar en tan sólo 16 inventarios: cinco de titularidad nobiliaria y altofuncionarial, dos eclesiásticos, y otros dos de licenciados y mercaderes, más uno de artesanos, los cuatro restantes pertenecen a ciudadanos sin adscripción socio-profesional conocida. Como dato añadido, hacer constar que el 73 por ciento de los registros contabilizados los encontramos inventariados a partir de 1600 .

Las otras grandes contribuciones al conocimiento del continente asiático estuvieron en las acreditadas obras de Amaro Centeno: Historia de Oriente (Córdoba, 1595), y en la descripción de las «muchas y muy extrañas cosas que vio y oyó» Fernando Méndez Pinto plasmadas en su Historia oriental de las peregrinaciones (Madrid, 1627). Mucho más original fue la obra de Juan Pedro Maffei: Historiarum indicarum que encontramos excepcionalmente en cuatro bibliotecas, una de ellas la del mercader en ganado Bartolomé Arnolfo (1650).

Un éxito de mayores proporciones estuvo en la Historia de las cosas más notables, ritos y costumbres del gran Reino de la China (1585) del agustino Juan González de Mendoza. Un texto que a tenor del medio centenar de ediciones cosechadas y de las múltiples traducciones vertidas a los principales idiomas europeos ${ }^{95}$, permite hacernos una idea de su considerable popularidad, más allá incluso de la segunda mitad del siglo XVII. Una notoriedad que con seguridad tomó mucho más cuerpo social gracias a las fidedignas fuentes de información empleadas: «así por los libros de los mesmos chinos, como por religiosos y otras personas que han estado en el dicho reino» ${ }^{96}$. Sería prolijo relacionar la importante acogida de esta obra entre el público alfabetizado madrileño, probablemente también entre el iletrado gustoso de escuchar oír noticias de lejanos países. En cualquier caso nos movemos - al igual que en las obras de Centeno y Méndez Pinto- en un enorme entramado de bibliotecas que confirman la idea de que se trata de obras ampliamente conocidas y reconocidas en nuestra ciudad, sin apenas diferenciaciones sociales, cronológicas ni porcentuales en cuanto a su posesión.

La conquista de noticias sobre Asia tuvo otros complementos historiales —algunos de menor calado editorial - como el editado en Barcelona en 1601

\footnotetext{
94 SÁNCHEZ Alonso, Benito: Historia de la bistoriografía..., op. cit., vol. I, p. 340.

95 Cfr. MARTIN, Henry-Jean: Livre, pouvoirs et société... op. cit., I, p. 210.

96 Cit. por López Piñero, José María: Ciencia y técnica..., op. cit., pp. 223 y 224.
} 
de Marcelo de Ribadeneyra: Historia de las islas del archipielago y reyno de la Gran China, Tartaria, Cuchinchina, Malaca, Sian..., o el de Antonio de Andrade sobre el Descubrimiento del gran Catayo o Reynos del gran Thibet (Segovia, 1628), obras que encontramos excepcionalmente en las bibliotecas del presbítero Francisco Manuel de Zamora (1650) y en la de consejero real Diego de Andrade (1642) respectivamente.

Penetrados, igualmente, por ese espíritu viajero de cumplir noticias de todo cuanto podía interesar sobre determinadas gentes y lugares, encontramos una pléyade de enunciados normalmente bien definidos en cuanto al contorno geográfico atendido, pero de difícilmente identificables al tratarse de descripciones por lo general abreviadas y del todo imprecisas. Entre otros casos ha sido posible descubrir apelativos como: «Un viaje a Jerusalén»; «Un libro del viaje a Tierra Santa»; «Viaje a la tierra de Jerusalén», o «Información de la Tierra Santa», etc. Un "Itinerario de Tierra Santa, en portugués», que identificamos con la obra de Pantaleao de Aveiro: Itinerario da Terra Sancta..., (Lisboa, 1600), estaba en posesión del platero de oro Simón Álvarez (1611). Desde este panorama correspondería mencionar al menos otros cuatro autores y sus respectivas obras a fin de aventurar posibles identificaciones: Antonio del Castillo: $E l$ deuoto peregrino y viage de Tierra Santa (Toledo: s.n., s.a.), Juan de Mandavila: Libro de las marauillas del mundo y del viage de la Tierra Santa... (Valencia, 1540), Antonio de Aranda: Verdadera información de la Tierra Sancta... (Toledo, 1545) y Fadrique Enríquez de Ribera, marqués de Tarifa: El viaje que bize a Ierusalem de todas las cosas que en el me pasaron... (Sevilla, 1606). A tenor del resultado de las consultas de los inventarios pueden avanzarse algunos datos concluyentes: la difusión de estos títulos fue más importante a medida que avanzaba la segunda mitad del siglo XVI, siendo el periodo 1600-1650 en donde se concentren el mayor número de identificaciones de este tipo y obras referidas ( 73 por ciento) que, a su vez, obtuvieron un generalizado eco en la ciudad llegando a la práctica totalidad de los alfabetizados madrileños. Sin duda, la generosa nómina de poseedores refleja en qué medida estuvo su popularidad: las hallamos entre los libros del boticario Francisco Frutos (1628), del barbero Domingo del Campo (1632), del familiar del Santo Oficio Juan Martínez Cortejudo (1600) y también en los de la viuda doña María de Trueba (1629), pasando por el interés de clérigos como Fernando de León (1599) y militares como Jerónimo de Soto (1630), hallándolos en el 61 por ciento de las bibliotecas de titularidad nobiliaria y altofuncionarial consultadas. Sin embargo, llama la atención el contraste entre esa abundancia y las escasas copias almacenadas en las tiendas de librería: valga como muestra la regentada por Cristóbal López (1606) en la que tan sólo hallamos cuatro "viajes de Jerusalén» vendidos a seis reales cada uno.

El interés lector demostrado por este género popular, evocador y entretenido es probable que contribuyera a que se editaran en nuestra ciudad otros títulos como el de Pedro Ordóñez de Ceballos: Viage del mundo... (Madrid, Luis Sánchez, 1614) que hallamos dispuesto para su venta en la tienda del librero Antonio Rodríguez (1623). Incluso las posibles expectativas comerciales que 
pudieron generar determinados títulos en su distribución, favorecieron la iniciativa de algunos profesionales a la hora de acumular imponentes depósitos de libros en papel impreso. Valga el caso del «Viaje a Constantinopla», obra que identificamos con la de Ogier Ghiselin de Busbecq: Embaxada y viages de Constantinopla..., Pamplona, 1610, que en número cercano a los novecientos ejemplares hallamos en la tienda de Jusepe Vidarte (1624).

Para terminar sólo comentar cómo el lector madrileño de manera similar estuvo abierto a otros títulos referidos a otros continentes como Africa. La alta difusión en Madrid de la obra del portugués Francisco Álvarez: Historia de las cosas de Etiopía (Anvers, 1557) prácticamente se iguala en número y distribución social a la citada Historia de China de González de Mendoza. Cualquier biblioteca madrileña relativamente bien dotada tampoco dejó de tener la famosa Descripción de Africa de Mármol Carvajal.

\section{A MODO DE CONCLUSIÓN}

Por todo lo visto hasta aquí, y considerando la práctica de la lectura de la historia como un fenómeno suficientemente adaptado al mundo de la edición y de lo urbano, incluso a las conformidades de las estructuras del poder, no es difícil presentir cómo la ciudad de Madrid se mantuvo a partir de mediados del siglo XVI en una óptima correspondencia cultural capaz de la consolidación del general conocimiento del pasado y de la particular cimentación del género historiográfico. Unas condiciones inmejorables para el estímulo de un público lector con inquietudes culturales y con ganas de apropiarse entre imágenes y hechos de aquellos acontecimientos que arrojaba su presente, sin olvidar de reconstruir y juzgar todos los que le precedieron. Es decir, las continuidades y las primicias historiográficas, los modelos vernáculos y extranjeros se combinaron en nuestras bibliotecas compartiendo circulaciones y receptividades.

Sin ser completos nuestros datos, los que hemos podido aportar sobre la literatura histórica en las bibliotecas particulares de los madrileños, permiten concluir que entre 1550 y 1650 se dio en la ciudad una progresión generaliza$\mathrm{da}$ en todos los sectores sociales y una más que progresiva ocupación lectora por los temas históricos que, además, conforme fue avanzando el tiempo conquistó posiciones cada vez más dominantes respecto de otras materias.

Significación análoga viene a tener el dato de que en nuestras bibliotecas cohabiten, sin grandes problemas, tanto primicias editoriales como memorias antiguas. Una compleja entremezcla temática de consumo historiográfico que con relativas y escasas diferencias (normalmente aparejadas al número de libros en propiedad) se deja ver indistintamente tanto entre los gustos de las clases dominantes, grupos profesionales como sectores populares. Por tanto, un primer resultado de nuestra investigación ha sido encontrar más que concretos tipos de lector, concretas iniciativas o tendencias de lectura. 
El material historiográfico masivo (y en buena parte nuevo) que nos hemos encontrado es un componente mayoritariamente escrito y leído en las llamadas lenguas vernáculas, y en la que a lo largo del periodo analizado se aprecia un cambio en el que, desde el sentido de continuidad con el pasado, su principal búsqueda del sujeto histórico empieza a perfilarse sobre el concepto de colectividad. Y todo gracias a la aplicación de más recursos narrativos y documentales que poco a poco fueron llegando a corresponderse con una realidad teóricamente más veraz, crítica y objetiva de los hechos.

En ese contexto el nuevo público lector se posibilitó de un diversificado abanico de temas: historia humanística; la cronística medieval y altomoderna; historias universales; el pasado italiano y la reciente realidad histórica de los Países Bajos; la descripción de la empresa americana; África, el problema turco y el lejano Oriente; la realidad corográfica; la historiografía greco-latina, etc. En suma, una historiografía completa y variada que respondía a una función de lectura teóricamente descomprometida y libre, pero que, sin embargo, al referirse a uno de los temas más recurrentes: la realidad de lo hispánico, se proyectará — como bien ha señalado García Cárcel - en varias direcciones: desde la glosa sacralizada de nuestros monarcas, pasando por la exaltación combativa de la lengua y cultura hispánicas, hasta los primeros epítomes envanecidos del esencialismo español ${ }^{97}$. Pero, en cualquier caso, siempre a través de una actitud marcada por la innovación y la modernidad, proyectando -en palabras de Sánchez Diana- sobre los «fundamentos intuitivos de un Tucídides, Tácito, o Polibio, el sello hispánico del realismo y de la sobriedad histórica» ${ }^{98}$.

La desigual dinámica editorial que afectó a determinados géneros literarios no se manifestó de similar manera con la producción historiográfica. La historia se benefició de una estrategia de mercado cuya creación, organización y divulgación vería ocupar un espacio representativo en los intereses libreros de la época, y como resultado inmediato en las propias iniciativas lectoras de los particulares. Una sociedad heterogénea en caudales intelectuales y sociales que bien supo valorar, recrearse, formarse y, en consecuencia, apropiarse de este tipo de literatura. Unas lecturas que, en consecuencia, se convirtieron - desde el más común de los mortales hasta el príncipe- en una escuela de juicio, lección, magisterio o de simple admonición, necesaria para analizar el curso constante de los hechos.

En suma, una sociedad que comienza a tener más elementos de comparación a la hora de distinguir las épocas, y ante la que se abre distintas y nuevas percepciones sobre la variedad y diversidad de los grupos humanos. Una sociedad, en su conjunto, que gracias a la historia empieza a ser consciente de su

97 GARCÍA CÁRCEL, Ricardo: «Los fantásticos relatos acerca de nuestra patria: la leyenda negra», en Historia Social, 3, (1989), p. 5.

98 SÁNCHEZ DiANA, José María: «El pensamiento historiográfico en la España de los Austrias», en Miscelánea de Estudios dedicados al profesor Antonio Marín Ocete, vol. II, Granada, 1974. pp. 969.

Hispania, LXV/3, núm. 221 (2005) 877-938 
modernidad y de la necesidad de ir impulsando desde el principio de continuidad y desde un renovado sentimiento de comunidad política y pertenencia ideológica, el adelanto de las modernas naciones.

Hispania, LXV/3, núm. 221 (2005) 877-938 